\title{
Retention of Sediments and Nutrients in the Iron Gate I Reservoir on the Danube River
}

\section{Journal Article}

Author(s):

Teodoru, Cristian; Wehrli, Bernhard

Publication date:

2005-12

Permanent link:

https://doi.org/10.3929/ethz-b-000057912

Rights / license:

In Copyright - Non-Commercial Use Permitted

Originally published in:

Biogeochemistry 76(3), https://doi.org/10.1007/s10533-005-0230-6 


\title{
Retention of sediments and nutrients in the Iron Gate I Reservoir on the Danube River
}

\author{
CRISTIAN TEODORU* and BERNHARD WEHRLI \\ Swiss Federal Institute for Environmental Science and Technology (EAWAG) and Swiss Federal \\ Institute of Technology (ETH), Limnological Research Center, Seestrasse 79, CH-6047, \\ Kastanienbaum, Switzerland; *Author for correspondence (e-mail: cristian.teodoru@eawag.ch; \\ phone: +41-41-349-21-51; fax: +41-41-349-21-68)
}

Received 13 December 2004; accepted in revised form 27 June 2005

Key words: Dam, Nitrogen, Nutrient retention, Phosphorus, Reservoir, Total suspended solids

\begin{abstract}
This work addresses an intensively debated question in biogeochemical research: "Are large dams affecting global nutrient cycles?" It has been postulated that the largest impoundments on the Lower Danube River, the Iron Gates Reservoirs, act as a major sink for silica ( $\mathrm{Si}$ ) in the form of settling diatoms, for phosphorus $(\mathrm{P})$ and to a lesser extent for nitrogen $(\mathrm{N})$. This retention of $\mathrm{P}$ and $\mathrm{N}$ in the reservoir would represent a positive contribution to the nutrient reduction in the Danube River. Based on a 9-month monitoring scheme in 2001, we quantified the nutrient and the sediment retention capacity of the Iron Gate I Reservoir. The sediment accumulation corresponded to $5 \% \mathrm{TN}$ (total nitrogen), $12 \% \mathrm{TP}$ (total phosphorus) and 55\% TSS (total suspended solids) of the incoming loading. A mass balance revealed that more $\mathrm{N}$ and $\mathrm{P}$ are leaving the reservoir than entering via the inflow. Based on these current results, the reservoir was temporarily acting as a small nutrient source. The nutrient accumulation in the sediments of the Iron Gate I Reservoir represents only $1 \%$ of the "missing" load of $10^{6} \mathrm{t} \mathrm{N}$ and $1.3 \times 10^{5} \mathrm{t} \mathrm{P}$ defined as the difference between the estimated nutrient export from the Danube Basin and the measured flux entering the Black Sea. This result disproves the hypothesis that the largest impoundment on the Danube River, the Iron Gates Reservoir, plays a major role in $\mathrm{N}$ and $\mathrm{P}$ elimination.
\end{abstract}

\section{Introduction}

The worldwide fresh water storage in rivers, natural lakes and reservoirs of $100,000 \mathrm{~km}^{3}$ represents $0.3 \%$ of the total fresh water resources (Morris and Fan 1997). The $7000 \mathrm{~km}^{3}$ of fresh water that is currently stored in reservoirs [compared to only $2100 \mathrm{~km}^{3}$ in natural rivers (Morris and Fan 1997)], could have a global impact on natural water resources. On a general scale, reservoirs have far-reaching effects not only on the hydrology, but also on biochemical and physical characteristics of continental waters. Damming rivers increases residence time and water temperature, decreases the turbidity, modifies thermal stratification and enhances in situ primary production. The construction of reservoirs also alters the organic carbon cycle, and the oxygen and nutrient balance (Friedl and Wüest 2002).

From the 1930 s to 1970 s, the construction of large dams became synonymous with development and economic progress, a symbol of modernisation 
and the ability to exploit natural resources. According to the World Commission of Dams (WCD 2000), about 800,000 dams have been built around the world, 45,000 of which are considered large dams (over $15 \mathrm{~m}$ high). In Europe, around 5500 large dams (WWF 2004) have significantly altered the natural flow and sediment transport in most European Rivers. The reduction of the river self purification capacity, changes in water quality, reduction of lateral exchange with groundwater, and biodiversity loss are only few of the consequences (Moroz 2003). As the second largest river in Europe after the Volga, the Danube River integrates different impacts. From its source in the Black Forest Mountains of Germany, it flows east over $2850 \mathrm{~km}$ across the continent to the Black Sea (Figure 1). With a large drainage basin of $817,000 \mathrm{~km}^{2}$ spanning 18 different countries, the Danube River is "the most international river in the world".

Many countries have built dams on the Danube with the purpose of hydropower generation, water supply, and flood control. The density of the dams on the Upper Danube (the first $1000 \mathrm{~km}$ ) reaches an average of one dam every $17 \mathrm{~km}$ (Zinke 1999). Among the large number of impoundments on the Danube and the tributaries, the Iron Gates is the largest dam and reservoir system by volume, area and hydropower potential. Located on the Lower Danube, approximately $900 \mathrm{~km}$ upstream from the Black Sea (Figure 1), the Iron Gates represents a typical, large run-of-the-river hydropower scheme with a considerable average discharge of $5600 \mathrm{~m}^{3} \mathrm{~s}^{-1}$. The reservoir has a total length of $205 \mathrm{~km}$, an area of $156 \mathrm{~km}^{2}$ holding a volume of $2.7 \times 10^{9} \mathrm{~m}^{3}$ (Table 1).

Increased nutrient loads in the Danube River basin led to serious ecological problems such as eutrophication along the Black Sea coast (Mee 1992). In the last decade, the reduction of mineral fertilisers used in the agriculture sector as well as the reduction of economic activities in Central and Eastern European countries decreased the N and P load (Zessner and Kroiss 1998). This most recent nutrient balance study indicated a considerable difference between the estimated nutrient export from the Danube Basin of up to 1150-1400 kt N yr${ }^{-1}$ and $140-190 \mathrm{kt} \mathrm{P} \mathrm{yr}^{-1}(1 \mathrm{kt}=1000$ metric tons) and the loads measured downstream entering the Black Sea of $400 \mathrm{kt} \mathrm{N} \mathrm{yr}^{-1}$ and 20-50 $\mathrm{kt} \mathrm{P} \mathrm{yr}^{-1}$. One of the hypotheses put forward to explain the incompatible results was that retention and subsequent losses of $\mathrm{N}$ and $\mathrm{P}$ play an important role especially in the large reservoirs like the Iron Gates (Perrsic et al. 1991; Gils 1999). Moreover, the construction of the two Iron Gates Reservoirs in the early 1970 has been postulated to represent the principal cause for the decrease in sediment and silica input into the Black Sea (Cociasu et al. 1996; Humborg et al. 1997), although the water discharge has not been significantly affected (Panin 1996). However, the most recent study on the Iron Gate I Reservoir indicated a present day dissolved silica (DSi) elimination in the range of only 4 to $5 \%$ of the total incoming load (Friedl et al. 2004; McGinnis et al, submitted), one order of magnitude lower than the previously postulated decrease of $75 \%$ (Cociasu et al. 1996; Humborg et al. 1997). Therefore, a more precise balance of $\mathrm{N}$ and $\mathrm{P}$ for Iron Gate $\mathrm{I}$ is of considerable interest. 


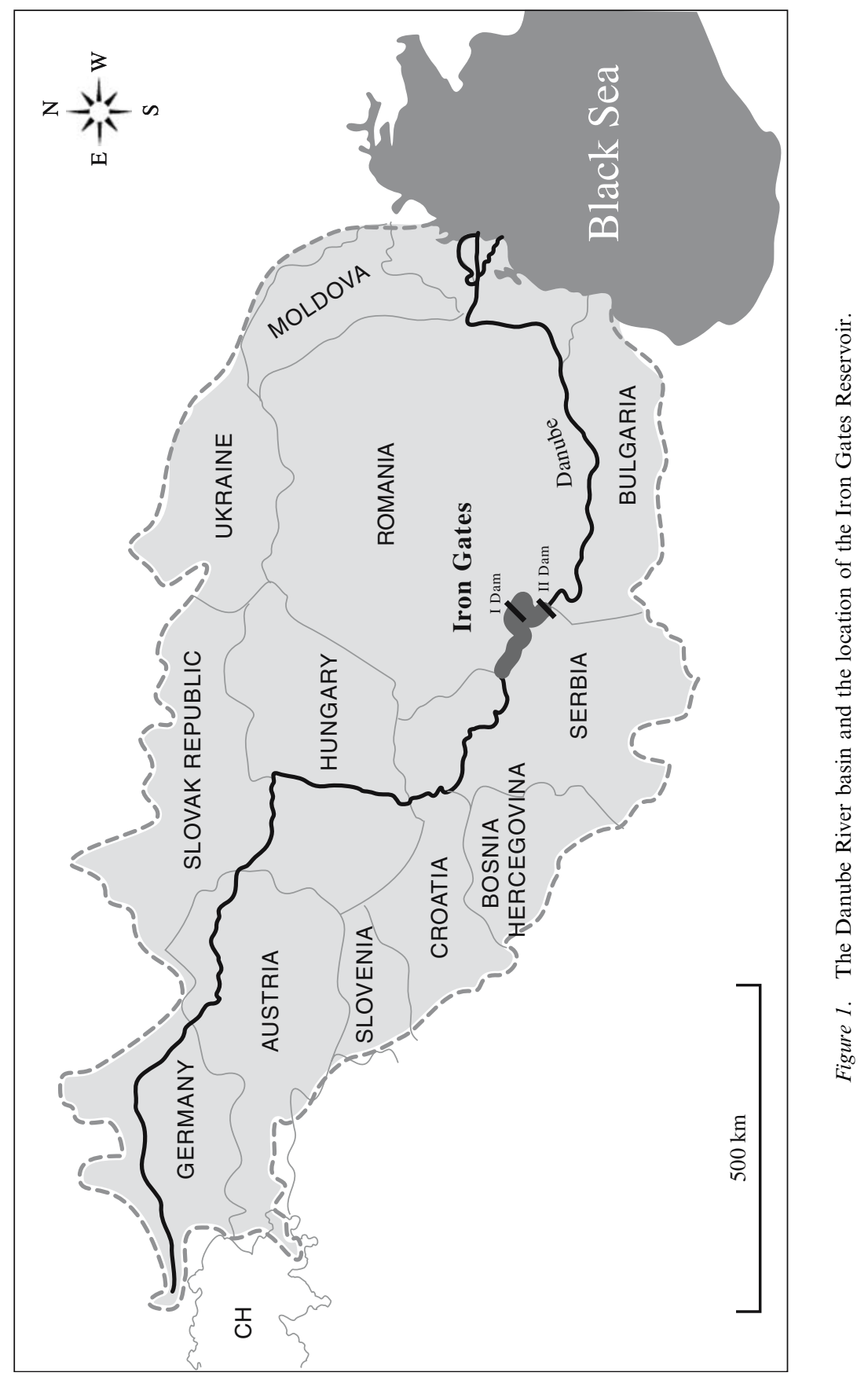


Table 1. The morphometric characteristics of the Iron Gates system according to the World Register of Largest Dams (AQUAPROIECT 2003).

\begin{tabular}{llllll}
\hline & $\begin{array}{l}\text { Dam } \\
\text { Height }(\mathrm{m})\end{array}$ & $\begin{array}{l}\text { Dam } \\
\text { Length }(\mathrm{m})\end{array}$ & $\begin{array}{l}\text { Volume } \\
\left(10^{9} \mathrm{~m}^{3}\right)\end{array}$ & $\begin{array}{l}\text { Area } \\
\left(\mathrm{km}^{2}\right)\end{array}$ & $\begin{array}{l}\text { Reservoir } \\
\text { Length }(\mathrm{km})\end{array}$ \\
\hline Iron Gates I & 60 & 1278 & 2.1 & 104.4 & 135 \\
Iron Gates II & 35 & 412 & 0.6 & 52 & 70 \\
Total & & & 2.7 & 156.4 & 205 \\
\hline
\end{tabular}

Based on weekly measurements of N, P, and total suspended solids (TSS) concentrations at the inflow, outflow and in one of the major bays, the present study quantifies the nutrient and sediment retention capacity of the Iron Gate I Reservoir. With additional sediment analyses and the observation of changes in the partitioning of particulate and dissolved $\mathrm{N}$ and $\mathrm{P}$, we address the question: which processes govern the input-output balance of nutrients in the reservoir?

\section{Study site}

The Iron Gates Reservoir marks the border between Romania and former Yugoslavia (Figure 1). The hydropower scheme consists of two dams: Iron Gate I Dam, a $1278 \mathrm{~m}$ wide overflow concrete dam with 14 spillways was constructed in 1971 at river $\mathrm{km} 942.4$ from the Black Sea, and the $1003 \mathrm{~m}$ wide Iron Gate II Dam, at river 864 was completed in 1984 (Batuca 2004). The water residence time calculated for both reservoirs based on the average water discharge of $5600 \mathrm{~m}^{3} \mathrm{~s}^{-1}$ is 6.5 days (Zinke 1999). According to the World Register of Largest Dams (AQUAPROIECT 2003), the upstream reservoir (Iron Gate I) with its length of $135 \mathrm{~km}$, an area of $104 \mathrm{~km}^{2}$ and a volume of $2.1 \times 10^{9} \mathrm{~m}^{3}$ (Table 1) accounts for more than $65 \%$ of the total length and area and $80 \%$ of the entire reservoir volume. In general, the channel section has a trapezoidal shape with depths varying between 10 and $53 \mathrm{~m}$ (mean depth of $25 \mathrm{~m}$ ) and 800 to $1300 \mathrm{~m}$ width (average width of $1040 \mathrm{~m}$ ), calculated from eight transects profiles along the reservoir. The Iron Gate II Reservoir, stretched from the Iron Gate I Dam to $70 \mathrm{~km}$ downstream, serves mainly for smoothing the peak flow operation. To provide a scientific assessment of the role of the Iron Gates Reservoir as a sediment and nutrient sink, a monitoring program was carried out between 1 February and 20 October 2001 focussing on the Iron Gate I Reservoir only.

Six monitoring stations included the inflow at Bazias (river km 1073), a station located $300 \mathrm{~m}$ upstream the confluence with Orsova Bay (km 955), one station in Orsova Bay and Cerna River and the outflow at a distance of $2 \mathrm{~km}$ in front of the Iron Gate I Dam (Figure 2). At each station, weekly water samples were collected at three different depths ( $1 \mathrm{~m}$, middle and bottom) within the water column using a Niskin bottle. The timing and the frequency of the 


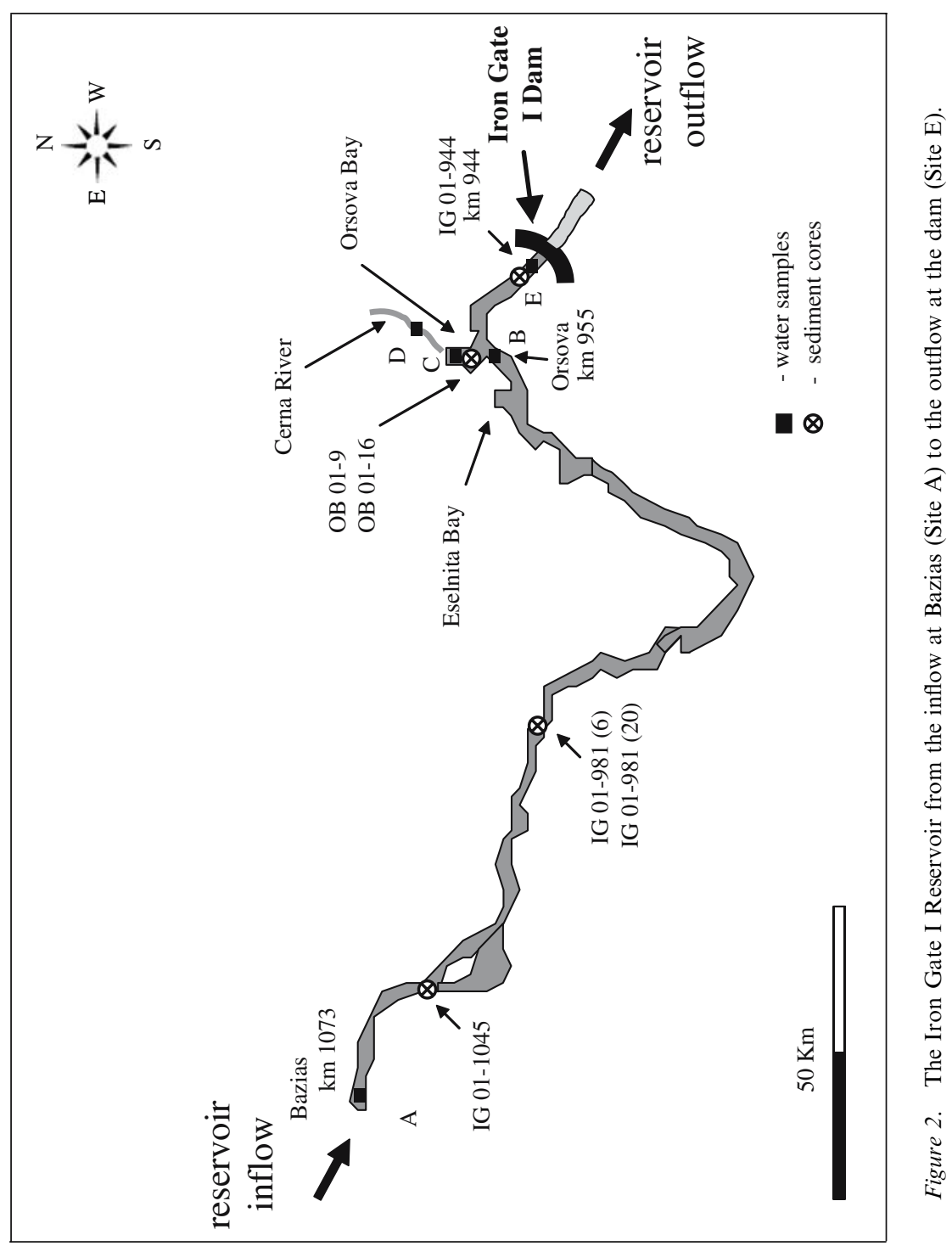


sampling scheme was not correlated to the flow regime due to the reliable assumption that for such a large river system the flow rate (Q) does not change dramatically within a few days. For instance, considering the volume of $2.1 \times 10^{9} \mathrm{~m}^{3}$ and the average flow rate of $5500 \mathrm{~m}^{3} \mathrm{~s}^{-1}$ measured during the year 2001, a flow velocity of $1.3 \mathrm{~km} \mathrm{~h}^{-1}$ can be calculated. This corresponds to a water residence time within the Iron Gate I Reservoir of 4.5 days. Anyway, the weekly sampling scheme has covered equally the high and the low flow during the sampling period.

The largest bay within the reservoir, Orsova Bay, was ascribed as a key site of sediment and silica retention (McGinnis et al. submitted). Outlined in Figure 2, Orsova Bay is located on the Romanian side of the reservoir near the town of Orsova (11 km upstream of the Iron Gate I Dam). The bay represents the old settlement of Orsova city, flooded after the dam construction and rebuild on higher ground. The surface area of Orsova Bay is $4.5 \mathrm{~km}^{2}$ representing $4.3 \%$ of the entire Iron Gate I Reservoir and it is separated from the Danube River by a sill of $5 \mathrm{~m}$ height. At the north end of the bay, the small Cerna River discharges at a rate of less than $5 \mathrm{~m}^{3} \mathrm{~s}^{-1}$.

Six sediment cores were obtained during the cruise in March 2001 using a gravity corer (Kelts et al. 1986). The locations are documented in Figure 2. Transported in up-right position, the cores were stored in the cool room at $4{ }^{\circ} \mathrm{C}$ until opened in 2002 in the EAWAG laboratory. Additionally, during the March cruise, two sediment traps were deployed: one at Orsova Bay, at a depth of $6 \mathrm{~m}$ (water depth $9 \mathrm{~m}$ ) and the other, $1 \mathrm{~km}$ in front of the dam at a depth of $26 \mathrm{~m}$ (water depth $31 \mathrm{~m}$ ). The accumulated sediment was collected monthly until October 2001.

\section{Method}

\section{Water analyses}

\section{Dissolved nitrogen and orthophosphate}

The water samples in duplicates were filtered immediately after sampling through a $0.45 \mu \mathrm{m}$ polycarbonate membrane and analysed within one day for nitrate $\left(\mathrm{NO}_{3}{ }^{-}\right)$, nitrite $\left(\mathrm{NO}_{2}{ }^{-}\right)$, ammonia $\left(\mathrm{NH}_{4}{ }^{+}\right)$and orthophosphate $\left(\mathrm{PO}_{4}{ }^{3-}\right)$ with a portable photometer (MERCK Spectroquadrant NOVA 60) following standard photometric methods (DEV 1996). Analytical errors were $3.5 \%$ for ammonia, $2.5 \%$ for nitrite, $6 \%$ for nitrate and $3 \%$ for orthophosphate.

\section{Total nitrogen and phosphorus}

A volume of $4 \mathrm{ml}$ unfiltered water samples was conserved for TN and TP analysis with $4 \mathrm{ml}$ solution of $2 \mathrm{~g}$ potassium peroxidisulfate and $0.3 \mathrm{~g}$ sodium hydroxide and diluted with distilled water to $100 \mathrm{ml}$ (DEV 1996). The samples were autoclaved at $120^{\circ} \mathrm{C}$ for two hours, stored in a cool room at $4{ }^{\circ} \mathrm{C}$, and analysed at EAWAG laboratory using a Techicon auto sampler and a 
Procon auto analyser. Analytical error was $5 \%$ for $\mathrm{N}$ and $1.5 \%$ for phosphorus.

\section{Water discharge}

The outflow ( $Q_{\text {out }}$ ) of the reservoir was measured at the Iron Gate I Dam by the hydropower company that operates the dam (HIDROELECTRICA S.A.). The inflow $\left(Q_{\text {IN }}\right)$ was calculated with a predictive algorithm using several upstream gauging stations and empirical flow velocities.

\section{Total suspended solids}

Light absorption and total suspended solids (TSS) measurements were performed on weekly water samples collected from three different depths within the water column. For the light absorption determination we used the MERCK Spectroquadrant NOVA 60 photometer at a wavelength of $665 \mathrm{~nm}$ (Kirk 1994; DEV 1996). Analytical error of the measurement was $2.5 \%$.

For the calibration of the photometric measurements, one litre water samples in duplicates were filtered through $47 \mathrm{~mm}$ diameter Watman GF/F fiber filters and dried at $105^{\circ} \mathrm{C}$ until the weight of the filters no longer changed. Total suspended solids were then determined gravimetrically with an error of $10 \%$ by relating the dry mass of the samples to the filtered volume (American Public Health Association 1998). A linear relationship (TSS $=86.24$ absorption units) with $R^{2}=0.94$ (Figure 3) was used to correlate the light absorption values to the TSS concentrations of 31 samples (Baker and Lavelle 1984).

\section{Sediment analyses}

The sediment cores from different locations within the Iron Gate I were cut into halves for description, photographed and sub-sampled at $1-\mathrm{cm}$ steps. The

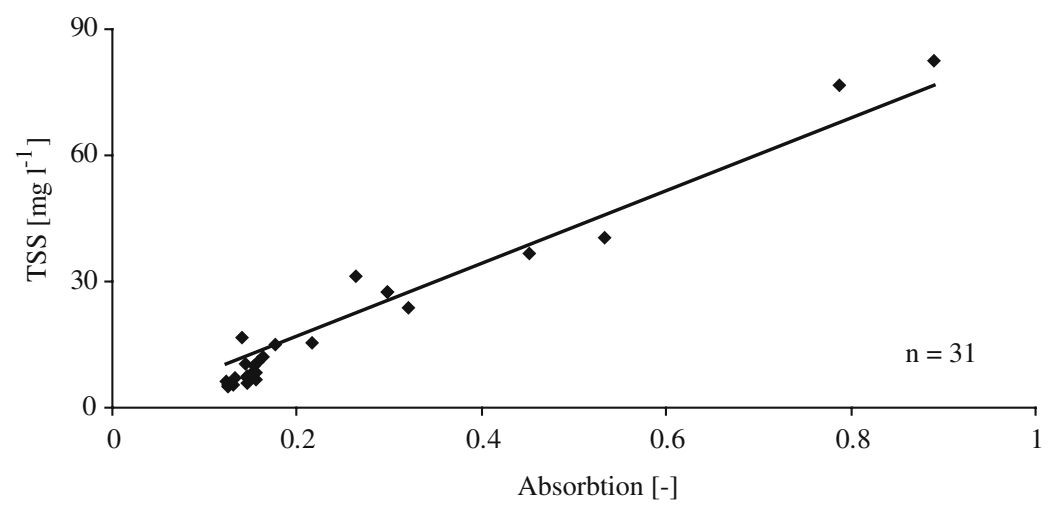

Figure 3. Linear correlation of the light absorption measurements and the total suspended solids concentration (TSS) from March and October 2001 cruises. Linear regression follows TSS $\left[\mathrm{mg} \mathrm{l}^{-1}\right]=86.24 \times$ Absorption units with $R^{2}=0.94$. 
wet sub-samples were freeze-dried for two days and the water content was determined.

\section{Dating}

Freeze-dried samples from the deepest core (16 m) of Orsova Bay (OB 01-16) and the core at $2 \mathrm{~km}$ in front of the dam (IG 01-944) were used for sediment chronology. The ${ }^{210} \mathrm{~Pb}$ dating method of Goldberg (1963) and Krishnaswami et al. (1971) was in agreement with the records of the artificial radionuclide ${ }^{137} \mathrm{Cs}$ (Pennington et al. 1973). The sedimentation rate $\left(\mathrm{cm} \mathrm{yr}^{-1}\right)$ calculations were corrected for compaction according to Appleby and Oldfield (1978) and Robbins (1978).

\section{Nitrogen}

For particulate organic nitrogen (PON) analyses, samples of approximately $25 \mathrm{mg}$ finely powdered sediment from traps and cores were suspended in $10 \mathrm{ml}$ $(0.5 \mathrm{M}) \mathrm{HCl}$ and sonicated for $4 \mathrm{~min}$ to remove inorganic carbonates. The aliquot was filtered on pre-combusted GF/F Whatman glass fibre filters. Additionally, $10 \mathrm{mg}$ sediment samples (cores and traps) were placed into aluminium cups for measurement of total nitrogen (TN). The TN and PON analyse were performed on a Perkin Elmer $2400 \mathrm{CHN}$ Elemental Analyser (DEV 1996). The analytical error of the measurements was $5 \%$.

\section{Phosphorus}

An application of the soluble reactive phosphorus (SRP) - ammoniummolybdate method to digested sediment was used to measure the total phosphorus (TP) content. As the organic phosphorus is not detected by the test unless it is first hydrolysed, $5 \mathrm{ml}$ solution of potassium peroxidisulfate was added to $10 \mathrm{mg}$ sediment and autoclaved at $120^{\circ} \mathrm{C}$ for $3 \mathrm{~h}$ (DEV 1996). This procedure liberates the organic phosphorus as orthophosphate and measured with the Procon auto-analyser. The analytical error of the measurements was $2.5 \%$.

\section{Results}

\section{Discharge}

The hydrological time series of the inflow at Bazias $\left(Q_{\mathrm{IN}}\right)$ was compared to the reservoir outflow $\left(Q_{\text {out }}\right)$ at the dam (Figure $4 a$ ). For a period of 12 months in 2001, the inflow and outflow showed the same trend. The highest flow rate of over $10,000 \mathrm{~m}^{3} \mathrm{~s}^{-1}$ was recorded on the 26th of April while the lowest value of $2500 \mathrm{~m}^{3} \mathrm{~s}^{-1}$ was reached during the first week of September. To test whether the year 2001 was an exceptional year concerning the hydrologic regime, the average flow of the year 2001 is compared to the time series of the annual flow measured $10 \mathrm{~km}$ below the Iron Gate I Dam at the station Drobeta-Turnu Severin (Figure 4b). Unfortunately, the Global River Discharge Database 

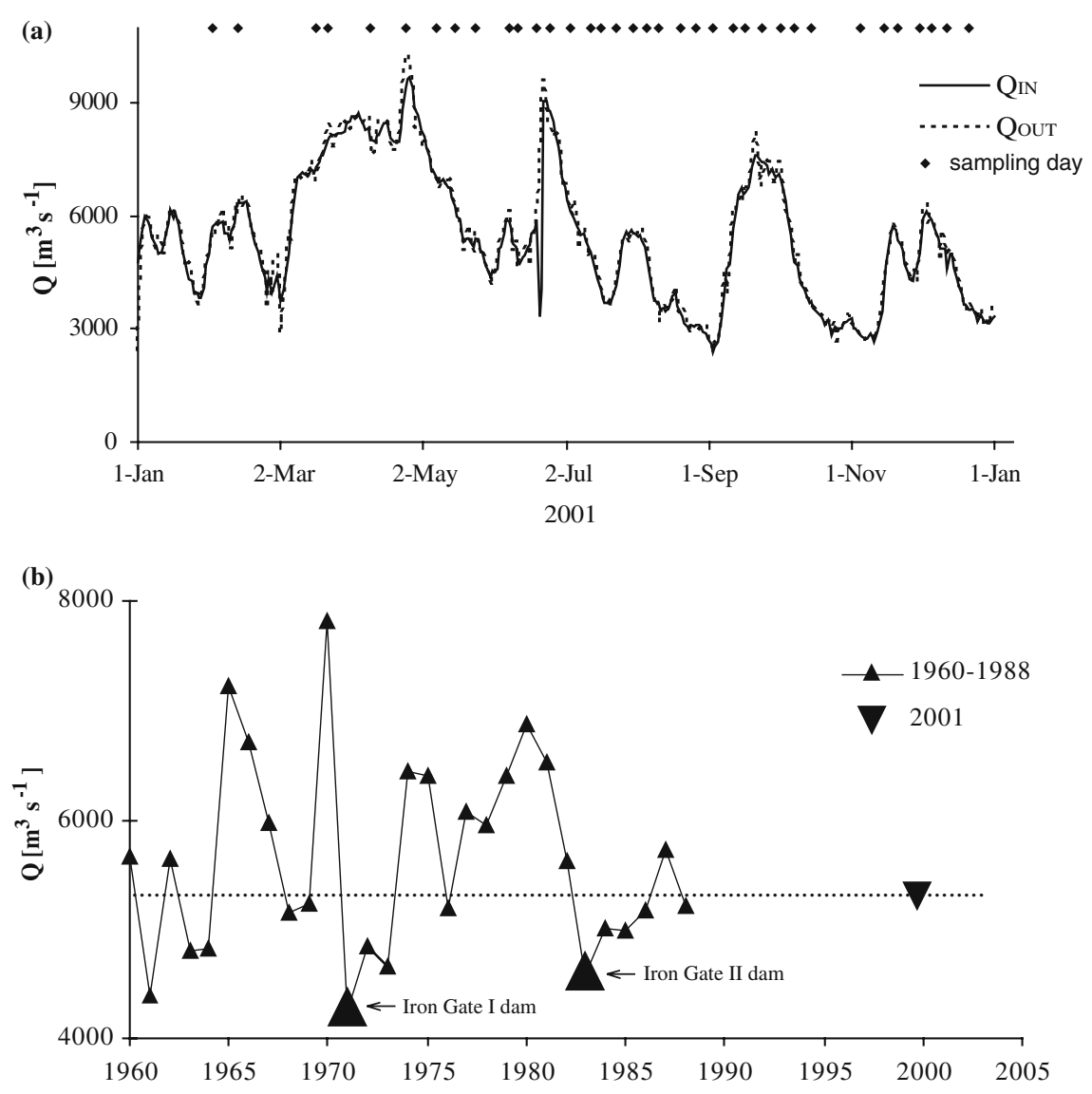

Figure 4. (a) The flow rate at Bazias $\left(Q_{\mathrm{IN}}\right)$ and at the dam $\left(Q_{\text {OUT }}\right)$ measured for the Iron Gate I Reservoir during the year 2001. The distribution of the black dots indicates the sampling frequency. (b) Time series flow rate at Drobeta-Turnu Severin station (approx. $10 \mathrm{~km}$ downstream Iron Gate I Dam) from 1960 to 1988 according to The Global River Discharge Database (RivDIS-v1.1 1994) and the average outflow at the dam for the year 2001.

(RivDIS-v1.1 1994) ends with the year 1988. The plot indicates that an average $\mathrm{Q}$ of $5500 \mathrm{~m}^{3} \mathrm{~s}^{-1}$ as for the year 2001 is comparable to the average $\mathrm{Q}$ of the time series 1960-1988 of $5450 \mathrm{~m}^{3} \mathrm{~s}^{-1}$. Therefore, 2001 was a normal year concerning the flow regime. Moreover, the rough estimates of 4.5 days average residence time suggest that the Iron Gate I Reservoir represents more a riverine system rather than a reservoir-lake (Friedl et al. 2004; McGinnis et al. submitted).

\section{Nutrient concentrations}

Three depth-concentrations (surface, middle and bottom) were determined at each station along the reservoir. The absence of a clear gradient, without 
significant vertical differences between the values characterised the nutrient distribution within the water column. The values presented below represent mean concentrations averaged over depth.

\section{Dissolved nitrogen and orthophosphate}

Dissolved inorganic nitrogen (DIN - as a sum of nitrite, nitrate, and ammonia) and orthophosphate inflow at Bazias are compared to the outflow concentrations at the dam for a first evaluation of the biogeochemical role of the reservoir (Figure 5a). The outflow DIN followed the pattern of the inflow concentrations. Slightly higher outflow concentrations were observed for almost the entire period except the beginning of February and end of April when the inflow concentration was about $17 \%$ higher than the outflow. The average DIN concentration over the entire period was $1.02 \mathrm{mg} \mathrm{N}^{-1}$ at Bazias and $1.11 \mathrm{mg} \mathrm{N}^{-1}$ at the dam suggesting an increase of almost $9 \%$ within the reservoir. Independently, a DIN source between Bazias and Iron Gate II dam was reported by Kröbel (2004) based on the database of ICPDR (2001).

The orthophosphate measurements at both stations indicated a similar higher outflow than inflow concentration (Figure 5b). The maximum concentration was observed in mid-July when the peak inflow exceeded the outflow by a factor of 2.5. The lowest concentration $\left(6 \mu \mathrm{g} \mathrm{P} 1^{-1}\right)$ was recorded in mid-May at the inflow (Bazias). The comparison between the average inflow and outflow concentrations of $32.1 \mu \mathrm{g} \mathrm{P} 1^{-1}$ and $51.3 \mu \mathrm{g} \mathrm{P} 1^{-1}$ revealed a $60 \%$ increase along the reservoir. To verify whether the difference between average inflow and outflow concentrations was significantly different, a paired $t$-test was applied. The results indicate that the inflow and outflow concentrations of DIN and orthophosphate are significant different at the 98.8 and $99.9 \%$ level.

\section{Total nitrogen and phosphorus}

The time series TN and TP inflow and outflow concentrations are compared for a period of 7 months. The TN outflow shows consistently higher values than the inflow with a maximum of about $1.4 \mathrm{mg} \mathrm{N}^{-1}$ and a minimum value of around $0.9 \mathrm{mg} \mathrm{N}^{-1}$ (Figure 5c). During the 7 month period, the inflow concentration at Bazias averaged $1.14 \mathrm{mg} \mathrm{N}^{-1}$ compared to the average at the dam of $1.28 \mathrm{mg} \mathrm{N}^{-1}$ indicating a $12 \%$ increase within the reservoir.

For TP, the difference between inflow and outflow were less pronounced. A maximum value of over $150 \mu \mathrm{g} \mathrm{P} \mathrm{1^{-1 }}$ was recorded at both stations at the end of June (Figure 5d). With an average value of $79.6 \mu \mathrm{g} \mathrm{P} 1^{-1}$ for the inflow and $84.5 \mu \mathrm{g} \mathrm{P} 1^{-1}$ for the outflow, the difference represented a $6 \%$ increase. According to the same paired $t$-test, the TN inflow-outflow concentrations were significantly different $(98.7 \%)$ whereas $\mathrm{TP}$ did not change significantly $(62.3 \%)$. 


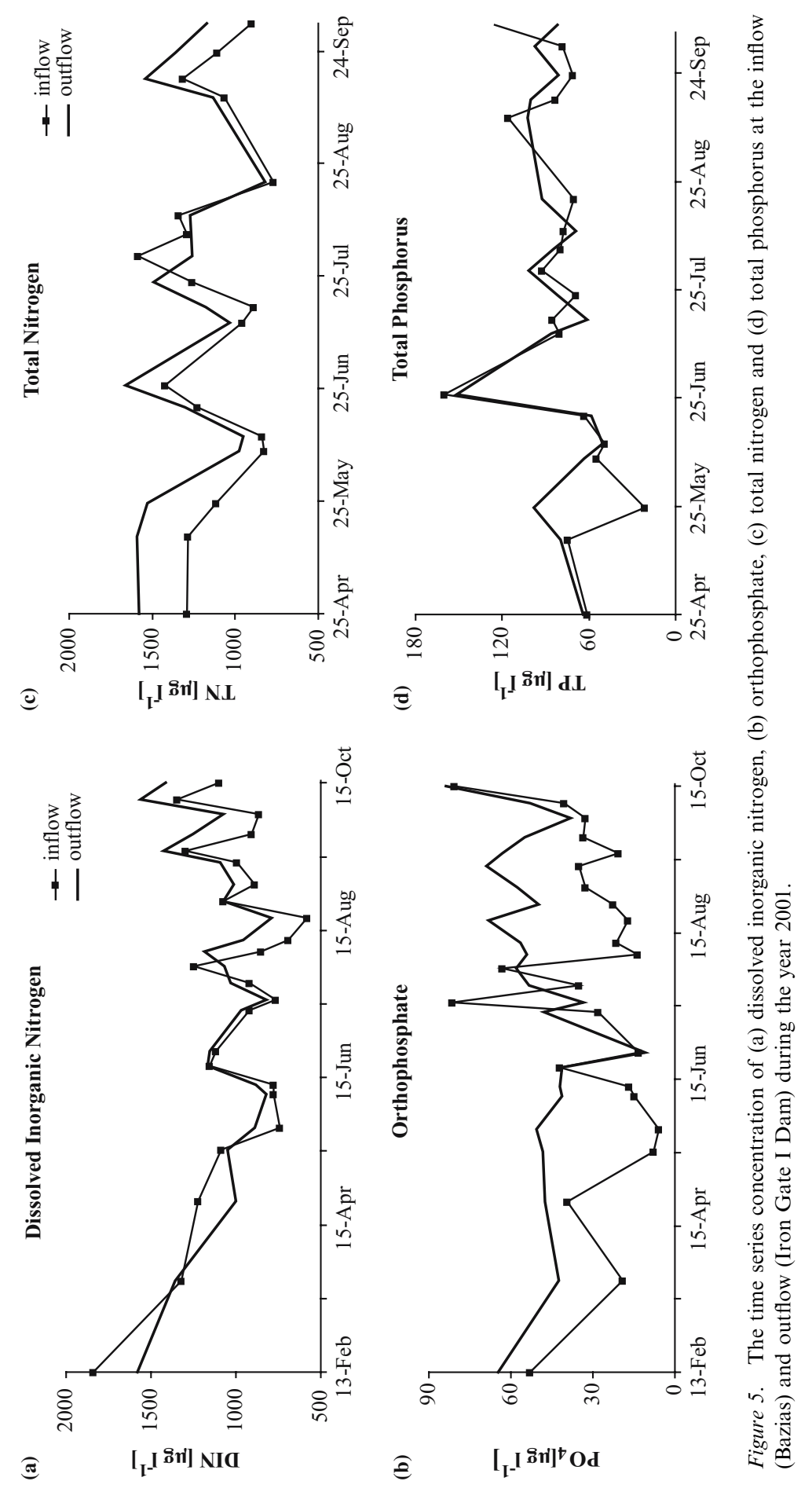




\section{The nutrient loads}

Loads of dissolved inorganic nitrogen and orthophosphate

The loads were calculated first by multiplying the concentrations by the discharge $(\mathrm{Q})$ of the sampling days. Then, the loads $\left(\mathrm{kt} \mathrm{day}^{-1}\right)$ were numerically integrated to determine the mass over the sampling period. The time series of DIN load showed slightly higher outflow than inflow. The total load for the studied period was $199 \pm 12 \mathrm{kt} \mathrm{N} \mathrm{yr}^{-1}$ at the outflow and $184 \pm 11 \mathrm{kt} \mathrm{N} \mathrm{yr}^{-1}$ at the inflow (Table 2). The difference between the annual input and output is close to the analytical error and represents an increase of $8 \%$ of the incoming flux or $15 \mathrm{kt} \mathrm{N} \mathrm{yr}^{-1}$.

The $\mathrm{PO}_{4}$ outflow was always higher than the inflow except for the 17th of July when an exceptionally high inflow was observed. In general, over the entire period the average orthophosphate outflow was of $9.6 \pm 0.3 \mathrm{kt} \mathrm{P} \mathrm{yr}^{-1}$ while the inflow was only $5.7 \pm 0.2 \mathrm{kt} \mathrm{P} \mathrm{yr}^{-1}$. The difference of $3.9 \mathrm{kt}$ between Bazias and the Iron Gate I Dam represents a significant increase of $68 \%$.

\section{Loads of total nitrogen and phosphorus}

The TN loads between April and October 2001 were quite variable with a range of 90 to $500 \mathrm{kt} \mathrm{N} \mathrm{yr}^{-1}$. The average output at the dam $\left(248 \pm 13 \mathrm{kt} \mathrm{N} \mathrm{yr}^{-1}\right)$ was almost $20 \%$ higher than the input at Bazias $\left(212 \pm 11 \mathrm{kt} \mathrm{N} \mathrm{yr}^{-1}\right)$ and translates into a $36 \mathrm{kt} \mathrm{N} \mathrm{yr}^{-1}$ increase within the reservoir.

TP load follows the concentration pattern with an exceptionally high value recorded in both stations at the end of June when reached $40 \mathrm{kt} \mathrm{P} \mathrm{yr}^{-1}$. This event was again related to a peak in the flow rate. The average inflow load at Bazias was $14.9 \pm 0.2 \mathrm{kt} \mathrm{P} \mathrm{yr}^{-1}$ compared to outflow of $16.5 \pm 0.2 \mathrm{kt} \mathrm{P} \mathrm{yr}^{-1}$ at the dam and represents an increase within the reservoir of $1.5 \mathrm{kt} \mathrm{P} \mathrm{yr}^{-1}$ or an enrichment of $10 \%$ (Table 2). A simply comparison between the inflow and outflow nutrient fluxes reveals no retention but suggests that the reservoir acts, at least temporarily, as a nutrient source. The data provides clear evidence for transformation of particulate $\mathrm{P}$ into dissolved $\mathrm{P}$ with an almost $70 \%$ higher dissolved P load at the outlet. Between April and October, no evidence for a net loss of DIN was found. To the contrary, the load of TN increased along the river stretch of the Iron Gate I Reservoir (Table 2).

Table 2. The average concentrations and loads of dissolved and total $\mathrm{N}$ and $\mathrm{P}$ at the inflow (Bazias) and outflow (dam) of the Iron Gate I Reservoir during the year 2001.

\begin{tabular}{|c|c|c|c|c|c|c|c|c|}
\hline & \multicolumn{2}{|l|}{ DIN } & \multicolumn{2}{|l|}{$\mathrm{TN}$} & \multicolumn{2}{|l|}{$\mathrm{PO} 4$} & \multicolumn{2}{|l|}{$\mathrm{TP}$} \\
\hline & $\left(\mathrm{mg} \mathrm{g}^{-}\right.$ & $\left(\mathrm{kt} \mathrm{yr}^{-1}\right)$ & $\left(\mathrm{mg} \mathrm{g}^{-}\right.$ & 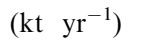 & $\left(\mathrm{mg} \mathrm{g}^{-1}\right.$ & $\left(\mathrm{kt} \mathrm{yr}^{-1}\right)$ & $\left(\mathrm{mg} \mathrm{g}^{-}\right.$ & $\left(\mathrm{kt} \mathrm{yr}^{-1}\right)$ \\
\hline inflow & 1.02 & $183.8 \pm 11.0$ & 1.14 & $211.7 \pm 10.6$ & 0.032 & $5.7 \pm 0.2$ & 0.079 & $14.9 \pm 0.2$ \\
\hline outflow & 1.11 & $198.6 \pm 11.9$ & 1.28 & $247.7 \pm 12.4$ & 0.051 & $9.6 \pm 0.3$ & 0.084 & $16.5 \pm 0.2$ \\
\hline$\%$ increase & & 8 & 12 & 17 & 59 & 68 & 6 & 11 \\
\hline
\end{tabular}




\section{Sedimentation and mass accumulation rate}

To quantify the role of sedimentation as a nutrient sink, we first assessed a sediment balance based on TSS measurements. These reservoir-wide sediment accumulation rates were then compared to the results of the local sediment core analyses. Together with the nutrient content of the sediments the net accumulation within the reservoir was determined.

\section{Mass balance of total suspended solids}

The sediment of rivers is usually divided into bed load moving along the river bed by rolling and sliding and suspended load that is supported by the fluid flow of the river and maintained in suspension by the upward component of turbulence. The proportion of bed load to suspended load varies from river to river but, in general, the larger the river the smaller the proportion that is attributable to bed load (Meade et al. 1990). For large rivers, such as the Danube, the bed load transport is typically small compared to the suspended load and therefore neglected in the following estimate.

The TSS concentrations used to assemble the sediment mass balance were measured weekly at the inflow (Bazias), near Orsova City - right upstream the confluence of the main channel with Orsova Bay (river km 955, Site B) and at the outflow (about $2 \mathrm{~km}$ upstream the dam, river $\mathrm{km} \mathrm{944)} \mathrm{(Figure} \mathrm{2).} \mathrm{The}$ average TSS for the year 2001 was $34 \mathrm{mg}^{-1}$ at Bazias and $17 \mathrm{mg}^{-1}$ at the dam. The values were comparable with the suspended solids concentrations of 25 and $4 \mathrm{mg}^{-1}$ for river $\mathrm{km} 1076.6$ and $\mathrm{km} \mathrm{954.6,} \mathrm{respectively,} \mathrm{determined} \mathrm{by}$ ICPDR (2004a). The calculation yielded an average TSS inflow load at Bazias of up to $8870 \pm 220 \mathrm{kt} \mathrm{yr}{ }^{-1}, 5520 \pm 138 \mathrm{kt} \mathrm{yr}^{-1}$ downstream at Orsova and $3890 \pm 97 \mathrm{kt} \mathrm{yr}^{-1}$ at the dam. For Orsova Bay Bocaniov (2002) and McGinnis et al. (submitted) estimated a water exchange of $14-26 \%$ of the river flow corresponding to a residence time of 0.5 days. As the bay is separated from the

Table 3. The sediment accumulation with the equivalent flux and sedimentation rate for three areas within the Iron Gate I Reservoir calculated from the total suspended solids (TSS) balance and sediment core analyses.

\begin{tabular}{lllcccc}
\hline Sedimentary zones & & $\begin{array}{l}\text { Sampling } \\
\text { site }\end{array}$ & $\begin{array}{l}\text { Area } \\
\left(\mathrm{km}^{2}\right)\end{array}$ & $\begin{array}{l}\text { Sediment } \\
\text { retention } \\
\left(\mathrm{kt} \mathrm{yr}^{-1}\right)\end{array}$ & $\begin{array}{l}\text { Sediment flux } \\
\left(\mathrm{g} \mathrm{m}^{-2} \mathrm{day}^{-1}\right)\end{array}$ & $\begin{array}{l}\text { Sedimentation } \\
\text { rate }\left(\mathrm{cm} \mathrm{yr}^{-1}\right)\end{array}$ \\
\hline Iron Gate I reservoir & & & 104.5 & 4980 & & $12.7-6.5$ \\
I. Bazias - Orsova & $\mathrm{TSS}^{\mathrm{a}}$ & $\mathrm{A}-\mathrm{B}$ & 91 & 3350 & 100.8 & 9.8 \\
II. Orsova Bay & $\mathrm{TSS}^{\mathrm{a}}$ & $\mathrm{C}$ & 4.5 & 165 & 100.5 & 9.8 \\
& core $^{\mathrm{b}}$ & $\mathrm{C}$ & 4.5 & 83 & 50.3 & 4.9 \\
III. Orsova - Iron Gate & $\mathrm{TSS}^{\mathrm{a}}$ & $\mathrm{B}-\mathrm{E}$ & 9 & 1465 & 446.0 & 43.4 \\
& core $^{\mathrm{c}}$ & $\mathrm{B}-\mathrm{E}$ & 9 & 786 & 239.4 & 23.3 \\
\hline
\end{tabular}

${ }^{a}$ from suspended solids measurements.

${ }^{b}$ from the bay sediment core analysis.

${ }^{c}$ results from Reschke (1999). 
main stream by a $5 \mathrm{~m}$ submerged sill, only the surface TSS concentrations were considered in the calculation of the bay input. The results indicate an annual

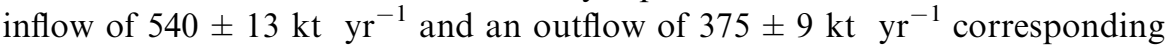

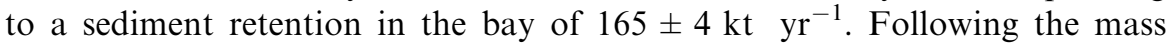
balance calculations, the TSS retention in the Iron Gate I Reservoir during the

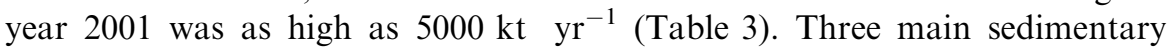
regions within the reservoir have been identified: (I) the first stretch from Bazias to Orsova (sites A to B) with a TSS retention per unit area of $101 \mathrm{~g} \mathrm{~m}^{-2} \mathrm{day}^{-1}$; (II) Orsova Bay (site C) with comparable rate of $100 \mathrm{~g} \mathrm{~m}^{-2} \mathrm{day}^{-1}$; (III) the lower stretch from Orsova to the dam (sites $\mathrm{C}$ to E) with the high rate of $446 \mathrm{~g} \mathrm{~m}^{-2} \mathrm{day}^{-1}$. A comparable sediment accumulation of $98 \mathrm{~g} \mathrm{~m}^{-2}$ day $^{-1}$ for the year 1950 and an average present day accumulation of $12.5 \mathrm{~g} \mathrm{~m}^{-2} \mathrm{day}^{-1}$ (average TSS concentration of $4 \mathrm{mg} \mathrm{l}^{-1}$ ) were calculated for a 37-km long natural lake (Lake Croix) formed on the St. Croix River due to its impoundment by a delta of the Mississippi River (Triplett et al. 2003). Using an average density of $2.5 \mathrm{~g} \mathrm{~cm}^{-3}$ and a porosity of $85 \%$, our values translate into a sedimentation rate of $9.8 \mathrm{~cm} \mathrm{yr}^{-1}$ for the first stretch and Orsova Bay, and four times higher value $\left(43.4 \mathrm{~cm} \mathrm{yr}^{-1}\right)$ between Orsova Bay and the dam. The three sedimentary areas were responsible for $68 \%, 3 \%$ and $29 \%$, respectively, of the total TSS retention.

\section{Sediment accumulation}

According to their length, two sediment cores from the Iron Gate I Reservoir were chosen for sediment chronology: the middle Orsova Bay core from a depth of $16 \mathrm{~m}$ (OB 01-16) and the core located $2 \mathrm{~km}$ in front of the dam (IG 01-944). Unfortunately, the core length of $38 \mathrm{~cm}$ of IG 01-944 at the dam was not enough to enclose the most recent ${ }^{137} \mathrm{Cs}$ peak of the Chernobyl event. Also, due to the particle remobilisation combined with the dilution effect from high accumulation rates, the ${ }^{201} \mathrm{~Pb}$ activities did not show a clear gradient. Reschke (1999) based his ${ }^{137} \mathrm{Cs}$ analyses on an over $2 \mathrm{~m}$ long core collected at the river $\mathrm{km} 947.2$ (almost $5 \mathrm{~km}$ upstream the dam). The calculated sedimentation rate corresponded to $23.3 \mathrm{~cm} \mathrm{yr}^{-1}$ or a bulk accumulation per surface area of $239.4 \mathrm{~g} \mathrm{~m}^{-2}$ day $^{-1}$ (Table 3).

The sedimentation rate of $4.9 \mathrm{~cm} \mathrm{yr}^{-1}$ calculated from the middle bay core (OB $01-16$ ) using ${ }^{210} \mathrm{~Pb}$ and supported by ${ }^{137} \mathrm{Cs}$ is in very good agreement with the value of $5 \mathrm{~cm} \mathrm{yr}^{-1}$ found by Reschke (1999) for the second largest bay within the reservoir (Eselnita Bay $-8 \mathrm{~km}$ upstream Orsova Bay; see Figure 2). With the measured porosity and density values of $85 \%$ and $2.5 \mathrm{~g} \mathrm{~cm}^{-3}$, respectively, the sediment accumulation rate for Orsova Bay was estimated to $50.3 \mathrm{~g} \mathrm{~m}^{-2} \mathrm{day}^{-1}$. This corresponds to annual sediment retention in the bay up to $82 \mathrm{kt} \mathrm{yr}^{-1}$ (Table 3). Comparable sedimentation rates between 1.5 and $11.5 \mathrm{~cm} \mathrm{yr}^{-1}$ were found based on ${ }^{137} \mathrm{Cs}$ measurements in 15 reservoirs on the Moldavian Plateau of Romania, the catchment of two Danube tributaries Siret and Prut Rivers (Ionita et al. 2000). Similar sedimentation rates between 1.4 to $21.4 \mathrm{~cm} \mathrm{yr}^{-1}$ have been documented in a study of 14 reservoirs in Puerto 
Rico (Soler-López 2001). Accordingly, the sedimentation rates in the Iron Gate I Reservoir of $4.9 \mathrm{~cm} \mathrm{yr}^{-1}$ for the upper stretch and Orsova Bay and $23.3 \mathrm{~cm} \mathrm{yr}^{-1}$ in front of the dam are characteristic for such a system. The almost two times higher values from the TSS balance compared to the sediment core analyses are conclusive if we consider that the sediment cores reflect a local situation integrated over a few decades whereas the TSS estimate is subject to large temporal fluctuations but integrated over a large area.

\section{Nutrient concentration in sediment}

From each sediment core within the reservoir, average TN, PON and TP were calculated for the top sediment representing the nutrient deposition over the year 2001 (Table 4). The TN and PON values from sediment trap samples were added for comparison. No TP was measured in sediment traps. The lowermost concentrations of $0.8 \mathrm{~N} \mathrm{~g}^{-1}$ and $0.12 \mathrm{mg} \mathrm{P} \mathrm{g}^{-1}$ characterised the upstream core (IG 01-1045) with an important sand fraction. At $60 \mathrm{~km}$ downstream (IG-981) the concentration increased almost 3 times, reaching values of $2.13 \mathrm{mg} \mathrm{N} \mathrm{g}^{-1}$ and $0.47 \mathrm{mg} \mathrm{P} \mathrm{g}^{-1}$ in the middle of the channel at a water depth of $20 \mathrm{~m}$. Slight higher values were observed at the same location, closer to the shore, at a water depth of $6 \mathrm{~m}\left(2.40 \mathrm{mg} \mathrm{N} \mathrm{g}^{-1}\right.$ and $\left.0.53 \mathrm{mg} \mathrm{P} \mathrm{g}^{-1}\right)$. Weighted averages of $1.90 \mathrm{mg} \mathrm{N} \mathrm{g}^{-1}$ and $0.40 \mathrm{mg} \mathrm{P} \mathrm{g}^{-1}$ were characteristic for this upper stretch of the reservoir (Bazias-Orsova Bay). The sediment cores from Orsova Bay (OB 01-9 and $\mathrm{OB}$ 01-16) show similar concentrations of about $2.6 \mathrm{mg} \mathrm{N} \mathrm{g}^{-1}$ and $0.5 \mathrm{mg} \mathrm{P} \mathrm{g}{ }^{-1}$ (Table 4) with representative averages of $2.57 \mathrm{mg} \mathrm{N} \mathrm{g}^{-1}$ and $0.55 \mathrm{mg} \mathrm{P} \mathrm{g}{ }^{-1}$. Only one core was available for the lower stretch from Orsova Bay to the dam. IG 01-944 showed TN concentration of $2.18 \mathrm{mg} \mathrm{N} \mathrm{g}^{-1}$ which

Table 4. Total nitrogen (TN), particulate organic nitrogen (PON) and total phosphorus (TP) concentrations of the top cores representing the sedimentary nutrient deposition during the year 2001.

\begin{tabular}{|c|c|c|c|c|c|c|}
\hline \multirow[t]{2}{*}{ Location } & & \multicolumn{2}{|l|}{ Coordinates } & \multirow{2}{*}{$\begin{array}{l}\mathrm{TN} \\
\left(\mathrm{mg} \mathrm{g}^{-1}\right)\end{array}$} & \multirow{2}{*}{$\begin{array}{l}\mathrm{PON} \\
\left(\mathrm{mg} \mathrm{g}^{-1}\right)\end{array}$} & \multirow{2}{*}{$\begin{array}{l}\mathrm{TP} \\
\left(\mathrm{mg} \mathrm{g}^{-1}\right)\end{array}$} \\
\hline & & $\mathrm{N}$ & $\mathrm{E}$ & & & \\
\hline I. Bazias - Orsova & & & & 1.90 & 1.65 & 0.40 \\
\hline IG $01-1045$ (15 m) & sediment core & $44^{\circ} 41^{\prime} 02.8^{\prime \prime}$ & $21^{\circ} 40^{\prime} 06.2^{\prime \prime}$ & 0.80 & 0.53 & 0.12 \\
\hline IG 01-981 (6 m) & sediment core & $44^{\circ} 32^{\prime} 33.8^{\prime \prime}$ & $22^{\circ} 12^{\prime} 41.9^{\prime \prime}$ & 2.40 & 2.10 & 0.53 \\
\hline IG 01-981 (20 m) & sediment core & $44^{\circ} 32^{\prime} 29.7^{\prime \prime}$ & $22^{\circ} 12^{\prime} 49.7^{\prime \prime}$ & 2.13 & 1.95 & 0.47 \\
\hline II. Orsova Bay & & & & 2.57 & 2.38 & 0.55 \\
\hline OB $01-9(9 \mathrm{~m})$ & sediment core & $44^{\circ} 43^{\prime} 30.0^{\prime \prime}$ & $22^{\circ} 24^{\prime} 33.7^{\prime \prime}$ & 2.55 & 2.40 & 0.57 \\
\hline OB $01-16(16 \mathrm{~m})$ & sediment core & $44^{\circ} 42^{\prime} 40.7^{\prime \prime}$ & $21^{\circ} 25^{\prime} 02.9^{\prime \prime}$ & 2.58 & 2.35 & 0.52 \\
\hline Orsova Bay (4 months) & sediment trap & $44^{\circ} 43^{\prime} 33.0^{\prime \prime}$ & $22^{\circ} 24^{\prime} 330^{\prime \prime}$ & 2.99 & 2.04 & - \\
\hline $\begin{array}{l}\text { III. Orsova - Iron } \\
\text { Gate I dam }\end{array}$ & & & & 2.18 & 2.06 & 0.20 \\
\hline IG 01-944 (24 m) & sediment core & $44^{\circ} 41^{\prime} 01.3^{\prime \prime}$ & $22^{\circ} 30^{\prime} 46.9^{\prime \prime}$ & 2.18 & 2.06 & 0.20 \\
\hline km 943 (7 months) & sediment trap & $44^{\circ} 41^{\prime} 00.2^{\prime \prime}$ & $22^{\circ} 30^{\prime} 230^{\prime \prime}$ & 2.48 & 1.73 & - \\
\hline
\end{tabular}

The sediment trap concentrations (italic) were added only for comparison. The bold values are mean concentrations calculated for each sedimentary area. 
compare well to the previous values whereas, with $0.20 \mathrm{mg} \mathrm{P} \mathrm{g}^{-1}$, TP was almost three times lower. In general, the recent sediment accumulated in the Iron Gate I Reservoir indicates an increase in nutrient concentrations toward the dam. The lowest value for TP at the dam may be explained by the dilution effect due to four times higher sediment accumulation rates and the appearance of suboxic to anoxic conditions below the sediment water interface leading to a reductive dissolution of $\mathrm{Fe}$-phases and concomitant P-release (Ingall et al. 1993; Ingall and Jahnke 1997).

The Iron Gate sedimentary nutrient concentration is two times lower compared to the Black Sea and Danube Delta lakes sediments. For instance, a sediment core from the shallow Rosu Lake (Danube Delta) revealed average concentrations of $8.3 \mathrm{mg} \mathrm{N} \mathrm{g}^{-1}$ and $1.09 \mathrm{mg} \mathrm{P} \mathrm{g}^{-1}$ whereas a Black Sea core in front of the Danube discharge (BLS.95-17) at a depth of $26 \mathrm{~m}$ was characterised by concentrations of $3.6 \mathrm{mg} \mathrm{N} \mathrm{g}^{-1}$ and $0.95 \mathrm{mg} \mathrm{P} \mathrm{g}^{-1}$ (Teodoru et al. submitted). The TP in the Iron Gate I Reservoir also appears low compared with TP data in the range of $1.8-3 \mathrm{mg} \mathrm{P} \mathrm{g}^{-1}$ measured in 8 sediment cores from the natural Lake Croix on the Mississippi River (Triplett et al. 2003). This comparison and the higher downstream nutrient concentrations suggest that primary production in the reservoir is marginal compared to the more productive delta lakes and the coastal zone. The sediment traps from the dam and Orsova Bay showed between $20 \%$ to $40 \%$ higher TN concentrations than the sediment cores indicating important remobilisation mechanisms.

The nutrient accumulation in the Iron Gate I Reservoir during the year 2001 was calculated by multiplying top-core sedimentary TN and TP concentrations with the TSS fluxes of each area (Table 5). As the TSS fluxes were found to be twice as high as the values from the sediment cores, the nutrient fluxes toward sediment ranging from 191 to $972 \mathrm{mg} \mathrm{N} \mathrm{m}^{-2}$ day $^{-1}$ and 40 to $89 \mathrm{mg} \mathrm{P}$ $\mathrm{m}^{-2}$ day $^{-1}$ represent upper estimates. Multiplying the nutrient fluxes with the area of the three sedimentary zones and summing up the results, the total nutrient mass that accumulates in the Iron Gate I Reservoir during the year 2001 was $10 \pm 0.5 \mathrm{kt} \mathrm{N} \mathrm{yr}^{-1}$ and $1.7 \pm 0.1 \mathrm{kt} \mathrm{P} \mathrm{yr}^{-1}$. A simple comparison with the inflow loads at Bazias indicate that only a small fraction up to $5 \% \mathrm{TN}$ and $12 \%$

Table 5. The nutrient fluxes and the sedimentary nutrient accumulation during the year 2001 for three areas within the Iron Gate I Reservoir.

\begin{tabular}{|c|c|c|c|c|c|c|}
\hline \multirow[t]{2}{*}{ Sedimentary area } & \multirow[t]{2}{*}{$\begin{array}{l}\text { Surface } \\
\text { area }\left(\mathrm{km}^{2}\right)\end{array}$} & \multirow{2}{*}{$\begin{array}{l}\text { Sediment } \\
\text { flux } \\
\left(\mathrm{g} \mathrm{m}^{-2} \mathrm{day}^{-1}\right) \\
\text { TSS }\end{array}$} & \multicolumn{2}{|c|}{$\begin{array}{l}\text { Nutrient flux } \\
\left(\mathrm{mg} \mathrm{m}^{-2}\right. \\
\left.\text { day }^{-1}\right)\end{array}$} & \multicolumn{2}{|c|}{ 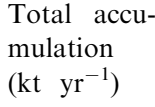 } \\
\hline & & & $\mathrm{TN}$ & $\mathrm{TP}$ & $\mathrm{TN}$ & $\mathrm{TP}$ \\
\hline Iron Gate I Reservoir & 104.5 & & & & 10.0 & 1.7 \\
\hline I. Bazias - Orsova & 91 & 100.8 & 191.3 & 40.3 & 6.4 & 1.3 \\
\hline II. Orsova Bay & 4.5 & 100.5 & 258.3 & 55.3 & 0.4 & 0.1 \\
\hline III. Orsova - Iron Gate & 9 & 446 & 972.3 & 89.2 & 3.2 & 0.3 \\
\hline
\end{tabular}

The total nutrient reservoir retention (bold) was calculated by summing up the results. 
TP of the input is presently removed by sedimentation. Higher rates between $29 \%$ and $47 \%$ of the TP incoming load were calculated to be retained by sedimentation in the Lake St. Croix between 1950 and 2000 (Triplett et al. 2003).

\section{Discussion}

\section{Decrease of suspended sediment loads}

Downstream effects of closing the Iron Gates were hitherto believed to cause a loss of particle fluxes to the coastal system of the Black Sea. Gastescu and Oltean (1997) gave a synthesis of the dynamics of the suspended solids entering the Danube Delta before and after the construction of the first Iron Gate Dam in 1970. According to their study, the total amount of suspended material transported by the Danube during the period 1921-1960 was $67,500{\mathrm{kt} \mathrm{yr}^{-1}}^{-1}\left(325 \mathrm{mg} \mathrm{l}^{-1}\right)$. The authors report a decrease of the annual sediment load from $41,300{\mathrm{kt} \mathrm{yr}^{-1}}^{-}\left(200 \mathrm{mg} \mathrm{l}^{-1}\right)$ in the period 1971-1980 to

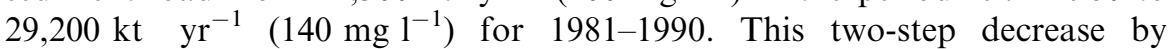
$26,000 \mathrm{kt} \mathrm{yr}^{-1}$ and $12,000 \mathrm{kt} \mathrm{yr}^{-1}$ was attributed to the construction of the Iron Gates Dams. The average suspended solids concentration of the year 2001 measured on the Danube River at Reni and Chilia stations (132 and $18 \mathrm{~km}$ from the Danube mouth, respectively) was only $19 \mathrm{mg} \mathrm{l}^{-1}$ and $25 \mathrm{mg} \mathrm{l}^{-1}$, respectively (ICPDR 2004a). This would represent a present load of 4000 to $5000 \mathrm{kt} \mathrm{yr}^{-1}$ and imply a third decrease by $25,000 \mathrm{kt} \mathrm{yr}^{-1}$ from 1990 to 2001. According to our results, TSS retention in the Iron Gate I Reservoir during the year 2001 was $5000 \mathrm{kt} \mathrm{yr}^{-1}$ and accounts for $56 \%$ of the incoming load. The present-day (2001) TSS input at Bazias of $9000 \mathrm{kt}$ $\mathrm{yr}^{-1}$ clearly shows that the sediment retention in the Iron Gates cannot exceed a value above its inflow.

Independently, a decrease in sediment load of between 20,000 and 30,000 kt $\mathrm{yr}^{-1}$ has been estimated by Humborg et al. (1997), Panin et al. (1999) and Zinke (1999) since the construction of the Iron Gates. A retention of $30,000 \mathrm{kt} \mathrm{yr}^{-1}$ representing $60 \%$ of the incoming load would require an inflow load of $50,000{\mathrm{kt} \mathrm{yr}^{-1}}$ with equivalent concentrations of about $170 \mathrm{mg}^{-1}$. Out measurements at Bazias show an average concentration of $33 \mathrm{mg}^{-1}$ for 2001 and imply that the input of suspended solids have been already reduced to a value five times lower than required for such a retention.

There are two possible sources for the discrepancies between our measurements and the estimates of earlier studies. First, most studies were based on only a few sediment core analyses and comparisons of historical suspended solids measurements. Our study has revealed differences of a factor of two between the input-output balance and sediment core analyses. Due to their superior integration over time and space, direct TSS measurements seem to be more reliable for assessing downstream impacts of large dams than extrapolations from sediment cores. Second, it is likely that a high number of 
smaller impoundments on head waters of the Danube catchment have a more pronounced effect on the sediment transport to the coastal zone than the construction of a single large reservoir. Moreover, the construction of many impoundments on the Danube tributaries downstream Iron Gates, is probably also responsible for decreasing particle transport from the Lower Danube to the Black Sea. According to the Word Commission of Dams (Zinke 1999), a total of 43 reservoirs with a storage capacity of $1.75 \times 10^{9} \mathrm{~m}^{3}$ on the Olt River and 88 hydropower dam-reservoirs with a store volume of $1.86 \times 10^{9} \mathrm{~m}^{3}$ on Siret River have been constructed prior and after the Iron Gates closure.

\section{The loss rate of reservoir capacity}

According to the Wold Register of Large Dams, the drainage area of the Iron Gate I Reservoir is $577250 \mathrm{~km}^{2}$ whereas the reservoir surface area is $104.4 \mathrm{~km}^{2}$ (Table 1) (AQUAPROIECT 2003). The average sedimentation rate for the entire reservoir corresponds to $12.7 \mathrm{~cm} \mathrm{yr}^{-1}$ (Table 3). Considering no major variation in sediment accumulation during the early stages of the reservoir until today, the sediment yield can be calculated as $23 \mathrm{~m}^{3} \mathrm{~km}^{2} \mathrm{yr}^{-1}$. Such a constant input would imply that in 30 years of usage, the storage capacity of the Iron Gate I Reservoir has been reduced by $19 \%$ from $2.1 \times 10^{9} \mathrm{~m}^{3}$ to $1.7 \times 10^{9} \mathrm{~m}^{3}$ which represents a long-term storage loss of $0.6 \%$ per year. Without technical measures, the useful reservoir life of the Iron Gate I would end after another 120 years. The estimate rate of storage loss agrees fairly well with an average loss of $0.7 \%$ annually for 14 reservoirs in Puerto Rico (Soler-López 2001) and a global estimate of $1 \%$ per year (Mahmood 1987).

\section{Sediment nutrient remobilisation}

The present-day negative nutrient balance of the Iron Gate I could be explained by remobilisation of $\mathrm{N}$ and $\mathrm{P}$ from older sediments deposited at times of higher nutrient loads. Down core profiles TN and TN concentration show a general decrease with increasing sediment depth (Figure 6). This could suggest increasing loads over the last decades or diagenetic remobilisation. Interpreting geochemical nutrient profiles can be problematic as the changes in concentrations can reflect both trends in nutrient loading and post-depositional recycling processes (Engstrom and Wright 1984; Anderson and Rippey 1994).

The historical development of the Danube nutrient loads over the last 50 years has been reconstructed by means of mathematical modelling (ICPDR 2004b). Accordingly, the DIN load of the year 2000 measured at the Danube River entering the Danube Delta was $27 \%$ lower than in 1985 (Figure 7a), whereas the TP load decreased by $40 \%$ compared to the maximum values in 1975 (Figure 7b) (ICPDR 2004b). In the absence of diagenetic mobilisation, 

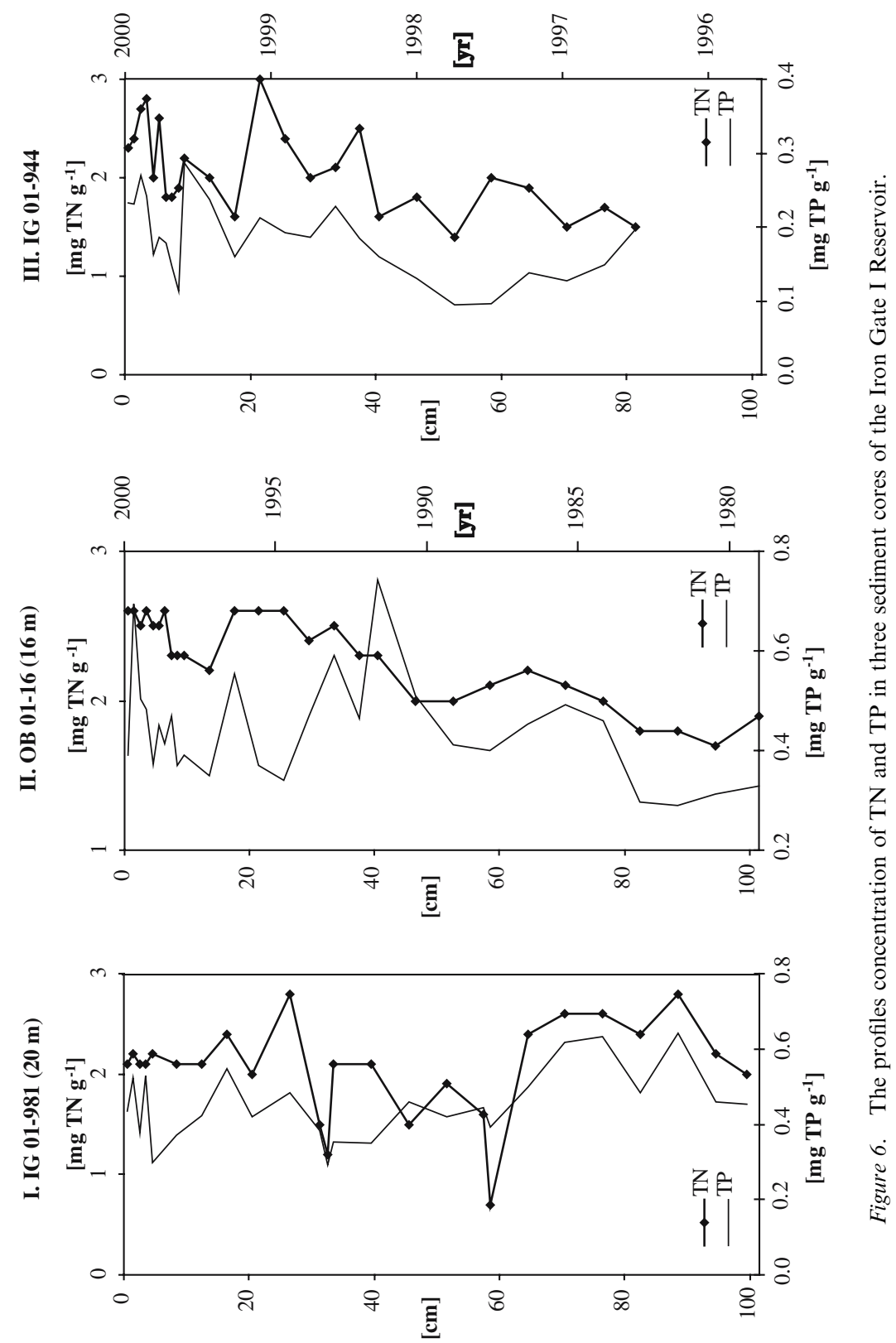

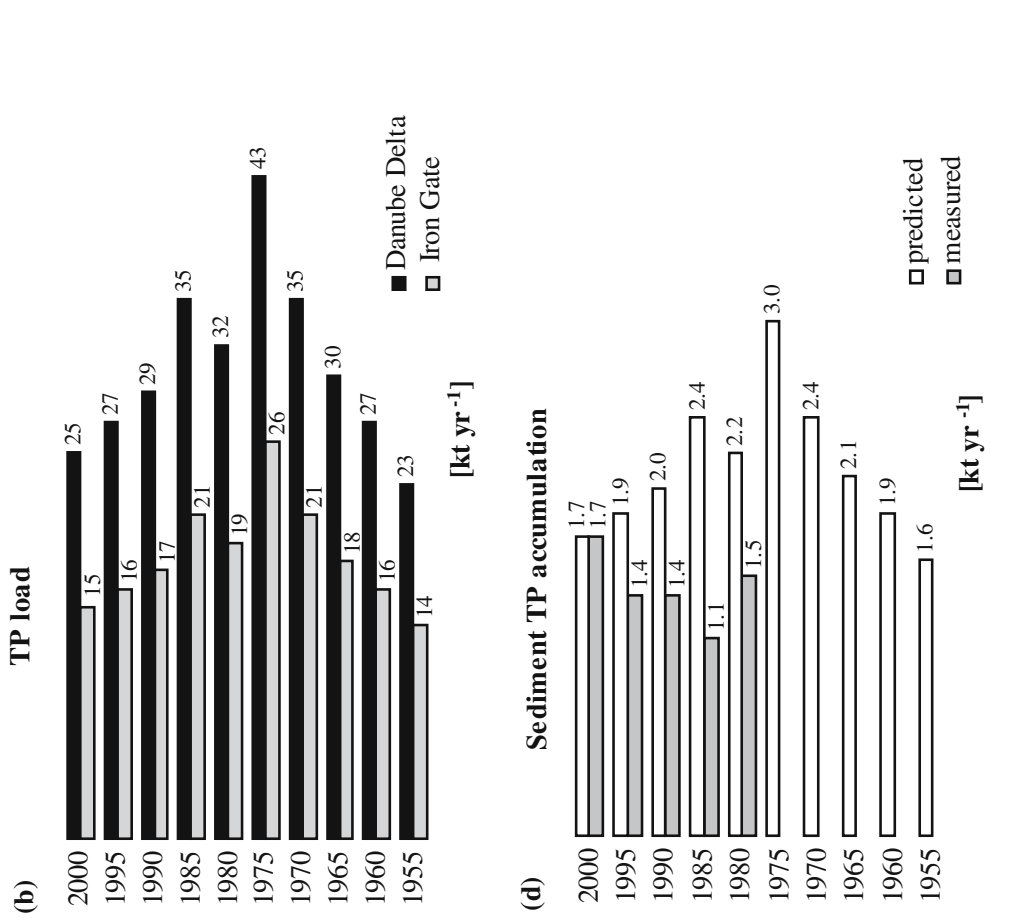

槖

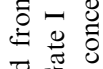

惫

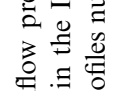

表专

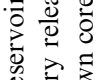

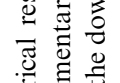

总总声

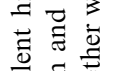

焉

它言

要

完言产

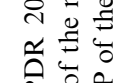

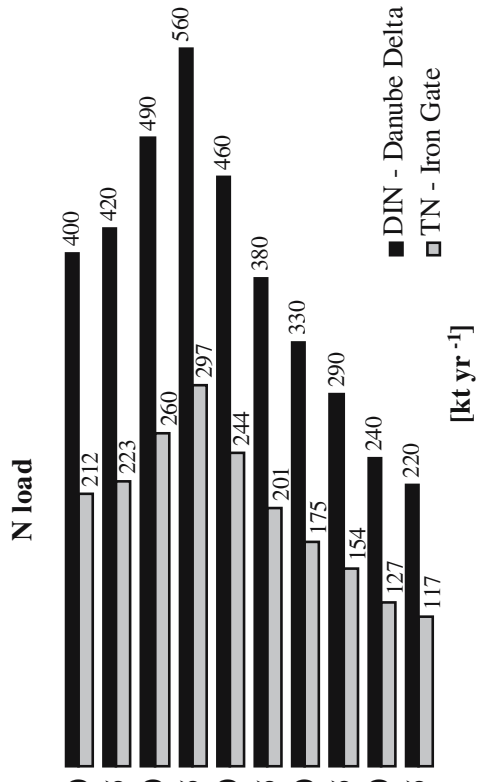

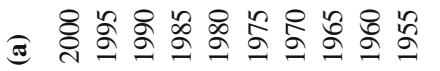

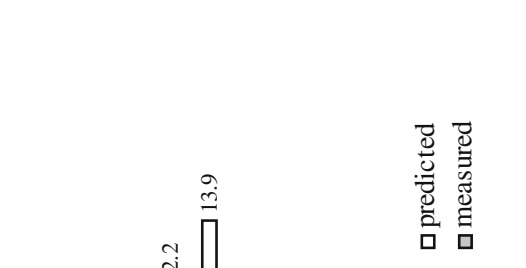

흘. 을

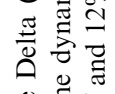

总艺

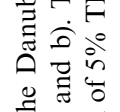

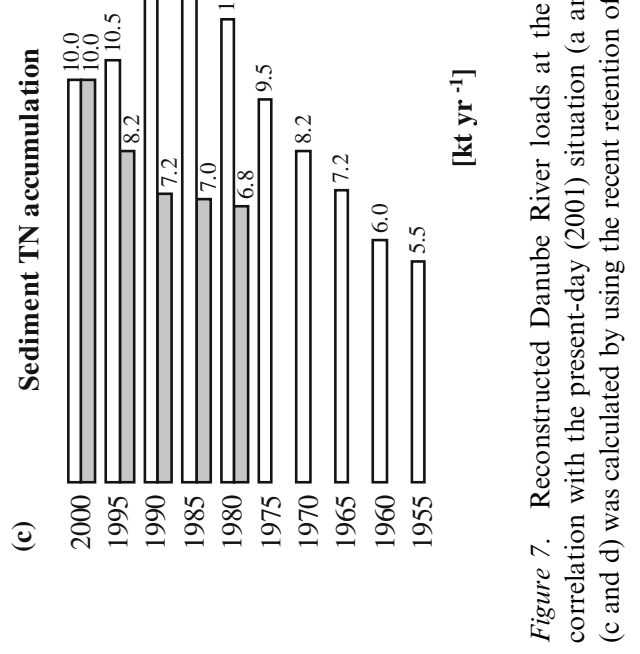


the nutrient concentrations in the early 1980's in the sediment of the reservoir should be higher compared to the present-day situation. The observations clearly indicate that remobilisation is a relevant process. To quantify the rate of nutrient release from the sediment we used a simple linear model for nutrient sedimentation (Gächter and Wehrli 1998). Although the sedimentary accumulation of nutrients (especially $\mathrm{P}$ ) may not be a linear function of the loading to the system (Triplett et al. 2003), the dynamic of sedimentary nutrient accumulation in the Iron Gate I Reservoir between 1955 and 2000 was reconstructed relying on the present-day accumulation of 5\% TN and 12\% TP of the incoming load (Figure 7a and b). From the down core profiles the net nutrient retention was calculated (Figure $7 \mathrm{c}$ and $\mathrm{d}$ ). The difference between the net retention and the predicted accumulation was interpreted as nutrient release. The rates varied from 2 to $7 \mathrm{kt} \mathrm{N} \mathrm{yr}^{-1}$ and 0.5 to $1.3 \mathrm{kt} \mathrm{P} \mathrm{yr}^{-1}$ with an average of $4.7 \mathrm{kt} \mathrm{N} \mathrm{yr}^{-1}$ and $0.8 \mathrm{kt} \mathrm{P} \mathrm{yr}^{-1}$. Compared to the reservoir outflow, the sediment nutrient release represents $2 \% \mathrm{TN}$ and $4.5 \% \mathrm{TP}$. Similar nutrient release rates of about $6 \% \mathrm{TP}$ were calculated for the sediment of Lake St. Croix (Triplett et al. 2003). Thus, the combined data from loading trends and sediment records provides evidence for significant nutrient release from older sediments which limits accumulation efficiencies of the reservoir sediments.

\section{Nutrient mass balance}

The total input into the reservoir including the inflow at Bazias and the lateral input from the subcatchment of the Iron Gate must be equal to the total losses including the output at the dam and the reservoir retention. As equation 1 define, at steady-state, the difference between the total input and output into the system must approach zero:

$$
L_{\mathrm{IN}}+L_{\mathrm{C}}-L_{\text {OUT }}-L_{\mathrm{S}}=0
$$

where $L_{\mathrm{IN}}$ and $L_{\mathrm{OUT}}$ stand for the in- and outflow loads, $L_{\mathrm{C}}$ represents the input from the subcatchment and $L_{\mathrm{S}}$ is the net retention in the sediment of the reservoir.

$L_{\mathrm{IN}}$ : The average inflow load at Bazias for the year 2001 was $212 \mathrm{kt} \mathrm{N} \mathrm{yr}^{-1}$ and $15 \mathrm{kt} \mathrm{P} \mathrm{yr}^{-1}$.

$L_{\mathrm{C}}$ : The lateral input was calculated from the values of nutrient emissions into surface waters of $14 \mathrm{~kg} \mathrm{~N} \mathrm{cap}^{-1} \mathrm{yr}^{-1}$ and $2 \mathrm{~kg} \mathrm{P} \mathrm{cap}^{-1} \mathrm{yr}^{-1}$ officially reported for Romania (EPDRB 1997). No values were available for Serbia. The subcatchment was estimated as $3000 \mathrm{~km}^{2}$ including both Romanian and Serbian territories. The population density of the Mehedinti County on the Romanian side was 66 inhabitants $\mathrm{km}^{-2}$ for the year 2000 and 95 inhabitants $\mathrm{km}^{-2}$ for the Serbian part (Encyclopaedia 2003). The average population density in the 
subcatchment represents approx. 80 inhabitants $\mathrm{km}^{-2}$. According to this scenario, the annual lateral input is $3.4 \mathrm{kt} \mathrm{N} \mathrm{yr}^{-1}$ and $0.5 \mathrm{kt} \mathrm{P} \mathrm{yr}^{-1}$.

$L_{\text {OUT }}$ : The outflow load pf TN and TP at the dam for the year 2001 was $248 \mathrm{kt}$ $\mathrm{N} \mathrm{yr}^{-1}$ and $16.5 \mathrm{kt} \mathrm{P} \mathrm{yr}^{-1}$.

$L_{\mathrm{S}}$ : The most recent sedimentary nutrient accumulation was $10 \mathrm{kt} \mathrm{N} \mathrm{yr}{ }^{-1}$ and $1.7 \mathrm{kt} \mathrm{P} \mathrm{yr}^{-1}$, out of which, $4.7 \mathrm{kt} \mathrm{N} \mathrm{yr}^{-1}$ and $0.8 \mathrm{kt} \mathrm{P} \mathrm{yr}^{-1}$ were released back into the water column. This result in a net retention of $5.3 \mathrm{kt} \mathrm{N} \mathrm{yr}^{-1}$ and $0.9 \mathrm{kt}$ $\mathrm{P} \mathrm{yr}^{-1}$. If all processes affecting the nutrient budget are included in the balance, the sum of annually loads should yield a $\Delta$ value close to zero (equation 2).

$$
L_{\mathrm{IN}}+L_{\mathrm{S}}-L_{\mathrm{OUT}}-L_{\mathrm{S}}=\Delta
$$

TN: $211.7+3.4-247.7-5.3=-37.9$

$$
\text { TP: } 14.9+0.5-16.5-0.9=-2
$$

The mass balance for TN (equation 3) and TP (equation 4) is shown schematically in Figure 8. With an average inflow load of $212 \mathrm{kt} \mathrm{N} \mathrm{yr}^{-1}$ and an average output of $248 \mathrm{kt} \mathrm{N} \mathrm{yr}^{-1}$, taking into account the lateral input and the net sedimentary nutrient retention, the presence in the system of an internal load ( $\Delta$ ) of up to $38 \mathrm{kt} \mathrm{N} \mathrm{yr}^{-1}$ is required. The same calculations for TP lead to

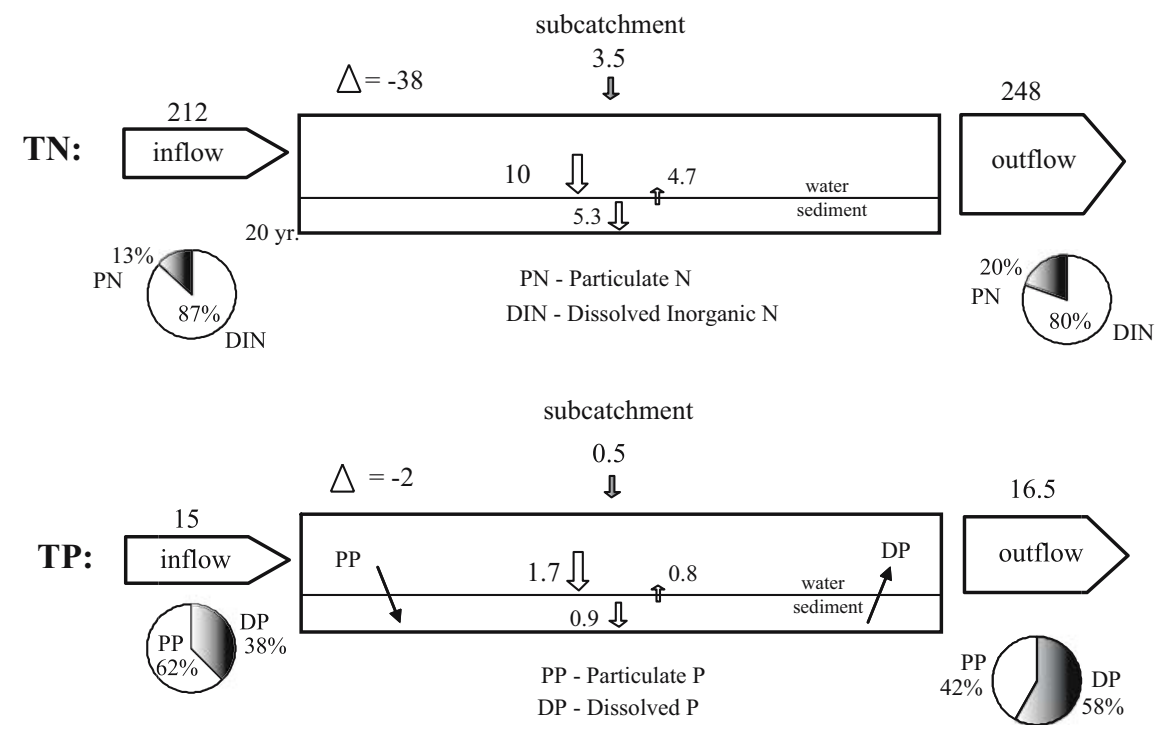

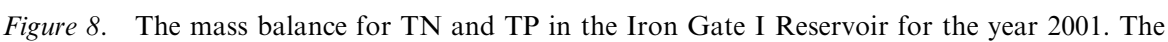

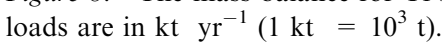


a $\Delta$ of $2 \mathrm{kt} \mathrm{P} \mathrm{yr}^{-1}$. Compared to the total input, the $\Delta$ load represents $18 \% \mathrm{TN}$ and $13 \% \mathrm{TP}$.

As Figure 8 indicates, the loss of particulate phosphate and an even larger increase in dissolved phosphate are the most significant processes in the flux balance. Overall, with a nutrient accumulation of $10 \mathrm{kt} \mathrm{N} \mathrm{yr}^{-1}$ and $1.7 \mathrm{kt} \mathrm{TP}$ $\mathrm{yr}^{-1}$ representing $5 \% \mathrm{~N}$ and $12 \% \mathrm{P}$ of the incoming load, the Iron Gate I Reservoir does not currently act as a significant nutrient sink. Even compared with the maximum accumulation of $14 \mathrm{kt} \mathrm{N} \mathrm{yr}^{-1}$ and $3 \mathrm{kt} \mathrm{P} \mathrm{yr}^{-1}$ during the period 1975-1985 (Figure 7) the fate of nutrient retention within the Iron Gate I Reservoir has not dramatically changed.

\section{Possible sources of the additional load}

In the following we briefly assess potential uncertainties and additional sources in the load balance. A part of the $38 \mathrm{kt} \mathrm{N}$ and $2 \mathrm{kt} \mathrm{P}$ internal load ( $\Delta$ ) may derive from higher emission into surface waters than the officially reported values of the year 1992 (EPDRB 1997). If the lateral input from the subcatchment area of the reservoir would be responsible for the entire $\Delta$, the recalculated specific TN and TP emissions would reach values of one order of magnitude higher (between 14 to $170 \mathrm{~kg} \mathrm{~N} \mathrm{cap}^{-1} \mathrm{yr}^{-1}$ and 2 to $10 \mathrm{~kg} \mathrm{P}$ $\mathrm{cap}^{-1} \mathrm{yr}^{-1}$ ). Such high nutrient emissions are quite unlikely even for countries as Romania and Serbia with a transitional economic stage. Anyway, due to the poor number of sewage treatment plants in the area, the possibilities of actually higher nutrient emission than latest reported should not be excluded.

Another possible source contributing to the uncounted load could be associated with point sources such as the small tributaries or industrial sewers. On the Romanian side, the largest river within the reservoir is represented by the Cerna River discharging into the Orsova Bay at a flow rate of less than $5 \mathrm{~m}^{3} \mathrm{~s}^{-1}$. No industrial activities in its catchment determined the load of Cerna up to $0.13 \mathrm{kt} \mathrm{N} \mathrm{yr}^{-1}$ and $0.005 \mathrm{kt} \mathrm{P} \mathrm{yr}^{-1}$ to represent only $0.3 \% \mathrm{TN}$ and $0.2 \%$ TP of the $\Delta$ load. On the Serbian side, the Pek River and the cooper mining activities in its catchment may represent an unknown additional source.

Internal loading by $\mathrm{P}$ release from sediments may be the most probable mechanism explaining the absence of a net P-retention in spite of the accumulation of particulate $\mathrm{P}$ (Figure 7). The sediment accumulated in front of the dam has a significant organic content associated and the highest settling rate. The TOC measurements from a sediment core situated $2 \mathrm{~km}$ upstream of the dam revealed an average concentration of $34 \mathrm{mg}$ TOC g $\mathrm{g}^{-1}$ and a bulk sedimentation rate between 23 and $43 \mathrm{~cm} \mathrm{yr}^{-1}$ (Table 3). Such sediments typically become anaerobic a few millimetres below the surface and reductive dissolution of iron oxides subsequently releases $\mathrm{P}$ to the interstitial water where it can migrate into the water column (Morris and Fan 1997). The rate of $P$ and $N$ release can be accelerated by sediment resuspension associated with high flow rates or bioturbation. These processes together with the uncertainties discussed 
above may explain a part of the imbalance in the input-output analysis. The nutrient released from the sediment of the Iron Gate I Reservoir was calculated to represent $4.7 \mathrm{kt} \mathrm{N}$ and $0.8 \mathrm{kt} \mathrm{P}$. Compared to the internal $\Delta$ load of $38 \mathrm{kt} \mathrm{N}$ $\mathrm{yr}^{-1}$ and $2 \mathrm{kt} \mathrm{P} \mathrm{yr}^{-1}$, the nutrient remobilisation represent 12 and $40 \%$, respectively. Even with a maximum release rate of $7 \mathrm{kt} \mathrm{N} \mathrm{yr}^{-1}$ and $1.3 \mathrm{kt} \mathrm{P} \mathrm{yr}^{-1}$ calculated for 1985 (Figure 7) the $\Delta$ load would not be totally achieved and most probably, its source is the combined effect of all the cases discussed before.

\section{Conclusions}

Based on the results of this study, the following general conclusions can be drawn:

1. The TSS balance for the Iron Gate I Reservoir during the year 2001 reveals a total sediment retention of $5000 \mathrm{kt} \mathrm{yr}^{-1}$ representing $56 \%$ of the incoming load at Bazias. The corresponding long-term storage loss of $0.6 \%$ per year has reduced the storage capacity of the reservoir by $20 \%$ after 30 years of usage. A comparison with previous estimates of the sediment retention between 20,000-30,000 kt $\mathrm{yr}^{-1}$ (Humborg et al. 1997; Panin et al. 1999) in the Iron Gates suggest that the system boundaries in those studies were not defined well enough. Damming the headwaters in the Danube catchment seems to have reduced the input of suspended solids to yearly

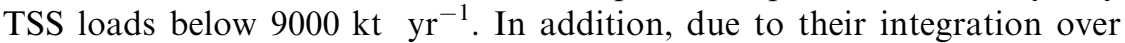
time and space, direct TSS measurements seem to be more reliable for assessing downstream impact of large dams than extrapolations from few sediment cores.

2. The input-output balance of $\mathrm{N}$ and $\mathrm{P}$ during the year 2001 revealed no evidence of a strong nutrient sink in the Iron Gate I Reservoir. To the contrary, a slight increase in nutrient loads of $18 \% \mathrm{TN}$ and $13 \% \mathrm{TP}$ was observed between Bazias and the dam. This surprising result reveals that nutrient storage in large reservoirs cannot be taken for granted.

3. Part of the discrepancy might be a consequence of nutrient remobilisation from older sediments. Dated sediment cores indicate a nutrient transfer across the sediment water interface. Early diagenesis seems to remobilise nutrients deposited between 1970 and 1990, when nutrient loads in the Danube where $30 \%$ to $40 \%$ higher than today. The release from the sediment of the Iron Gate I Reservoir was calculated to represent as much as $47 \%$ of the present-day sedimentary nutrient accumulation, contributing to the internal loading $(\Delta)$ with $12 \% \mathrm{TN}$ and $40 \% \mathrm{TP}$. In a general context our observations reveal that sediments in large reservoirs may retain a memory of past nutrient loadings, which might induce a hysteresis effect and slow down the recovery of downstream system after a reduction in nutrient loads.

4. The estimated total nutrient accumulation for the year 2001 of $10 \mathrm{kt} \mathrm{N} \mathrm{yr}^{-1}$ and $1.7 \mathrm{kt} \mathrm{P} \mathrm{yr}^{-1}$ represent $5 \% \mathrm{TN}$ and $12 \% \mathrm{TP}$ of the reservoir incoming load. Compared to the "missing load" of $1000 \mathrm{kt} \mathrm{N} \mathrm{yr}^{-1}$ and $130 \mathrm{kt} \mathrm{P} \mathrm{yr}^{-1}$ 
defined as the difference between the estimated loads into surface waters of the Danube Basin and the measured downstream loads entering the Black Sea (Zessner and Kroiss 1998), the nutrient retention in the Iron Gate I Reservoir represents only $1 \%$. This study did not support the hypothesis that the largest impoundment on the Danube River, the Iron Gate I Reservoir, played a major role in TN and TP elimination. The cumulative effect of the large number of dams along the aquatic continuum from land to ocean has to be considered in the assessment of the TSS and nutrient sink.

\section{Acknowledgments}

We would like to first thank our project leader Gabriela Friedl, our colleagues Alfred Wüest, Dan McGinnis, Andreas Lorke and Michael Schurter from the Department of Applied Aquatic Ecology, Christian Dinkel from the Department of Surface Water at EAWAG and also our Romanian colleagues from the National Institute of Marine Geology and Geo-Ecology (GeoEcoMar) in Bucharest for their support during the sampling cruises and the helpful discussions. The study was supported by the SCOPES - a program of the Swiss National Science Foundation (Grant 200020-103827.1).

\section{References}

American Public Health Association 1998. Total Suspended Solids dried at 103-105 degrees Celsius Method. In: Standard Methods for the Examination of Water and Wastewater, 2540D. 20 th ed. Washington, DC pp. 2-57-2-58.

Anderson N.J. and Rippey B. 1994. Monitoring lake recovery from point-source eutrophication: the use of diatom-inferred epilimnetic total phosphorus and sediment chemistry. Freshwat. Biol. 32: 625-639.

Appleby P.G. and Oldfield F. 1978. The calculation of ${ }^{210} \mathrm{~Pb}$ assuming a constant rate of supply of unsupported ${ }^{210} \mathrm{~Pb}$ to the sediment. Catena 5: 1-8.

AQUAPROIECT 2003. Dams in Romania: World Register of Largest Dams - Folios Concerning Romania (Portile de Fier), www.dams.go.ro/rrmb/rrmb_d3.htm.

Baker E.T. and Lavelle J.W. 1984. The effect of particle size on the light attenuation coefficient of natural suspensions. J. Geophys. Res. 89: 8197-8203.

Batuca D.B. 2004. Water Flow and Sediment Transport in the Lower Danube River - Romanian Retrospective and Perspective. Presentation at 3rd SedNet Conference: The Future of Sediment Management in Europe, Nov. 25-26 2004, Venice.

Bocaniov S. 2002. Hydrodynamics and Sediment-related Nutrient Retention in the Lower Reach of the Iron Gate I Reservoir (Danube River, Romania). M. Sc. Thesis (EST 02. 16), Department of Environmental Research of the International Institute for Infrastructural, Hydraulic and Environmental Engineering (IHE Delft), The Nederlands.

Cociasu A., Dorogan L., Humborg C. and Popa L. 1996. Long-Term Ecological Changes in Romanian Coastal Waters of the Black Sea. Mar. Pollut. Bull. 32(1): 32-38.

DEV 1996. Deutsche Einheitsverfahren zur Wasseruntersuchung (DEW). VCH Weinheim, New York.

Encyclopedia 2003. Mehedinti County. www.nationmaster.com/encyclopedia/Mehedinti.

Engstrom D.R. and Wright H.E.J. 1984. Chemical stratigraphy of lake sediments as a record of environmental change. In: Lund J.W.G. and Haworth E.Y. (eds), Lake Sediments and Environmental History. University of Leicester Press, Leicester, pp. 11-67. 
EPDRB 1997. Nutrient Balance for Danube Countries - Project EU/AR/102A/91. Final Report.

Friedl G., Teodoru C. and Wehrli B. 2004. Is the Iron Gate I Reservoir on the Danube River a sink for dissolved silica? Biogeochemistry 68: 21-32.

Friedl G. and Wüest A. 2002. Disrupting biogeochemical cycles - Consequences of damming. Aquat. Sci. 64: 55-65.

Gastescu P. and Oltean M. 1997. Ecosystems of the Romanian Danube Delta Biosphere Reserve. Explanation to the map 1:175 000. RIZA, document 99.032x, PDF file available at http:// www.riza.nl/index_uk.html.

Gächter R. and Wehrli B. 1998. Ten years of artificial mixing and oxygenation: no effect on the internal phosphorus loading of two eutrophic lakes. Environ. Sci. Technol. 32: 3659-3665.

Gils J.V. 1999. Danube pollution reduction programme: transboundary analysis and the pollution reduction programme. UNDP/GEF, Delft.

Goldberg E.D. 1963. Geochronology with ${ }^{210} \mathrm{~Pb}$. Radioactive Dating. I.A.E.A., Vienna, pp. 121-131.

Humborg C., Ittekkot V., Cociasu A. and Bodungen B.V. 1997. Effect of Danube River dam on Black Sea biochemistry and ecosystem structure. Nature 386: 385-388.

ICPDR 2001. International Commission for the Protection of the Danube River. TNMN Yearbook 1997-2000, www.icpdr.org.

ICPDR 2004a. Water Quality in the Danube River Basin. TNMN-Yearbook 2001, www.icpdr.org.

ICPDR 2004b. The Danube River Basin District, Part A - Basin-wide overview. WFD Roof Report 2004, www.icpdr.org.

Ingall E.D., Bustin R.M. and Van Cappellen P. 1993. Influence of water column anoxia on the burial and preservation of carbon and phosphorus in marine shales. Geochim. Cosmochim. Acta 57(2): 303-316.

Ingall E.D. and Jahnke R. 1997. Influence of water-column anoxia on the elemental fractionation of carbon and phosphorus during sediment diagenesis. Mar. Geol. 139(1-4): 219-229.

Ionita I., Margineanu R.M. and Hurjui C. 2000. Assessment of the reservoir sedimentation rates from ${ }^{137} \mathrm{Cs}$ measurements in the Moldovian Plateau. Acta Geologica Hispanica 35(3-4): 357-367.

Kelts K., Briegel U., Ghilard K. and Hsü K. 1986. The limnologeology - ETH coring system. Schweiz. Z. Hydrol. 48(1): 104-115.

Kirk J.T.O. 1994Light and photosynthesis in aquatic ecosystems. Press Syndicate of the University of Cambridge, UK.

Krishnaswami S., Lal D., Martin J.M. and Meybeck M. 1971. Geochronology of lake sediments. Earth Planet. Sci. Lett. 11: 407-414.

Kröbel R. 2004. Comparison of RivR N-, Sparrow- and WASP 6.0-model calculating the DIN fluxes in the Danube River and the influence of the Iron Gate dam lakes on these fluxes. M. Sc. Thesis, Wageningen University and Research Centre (WUR), Department of Environmental System Analysis (ESA), The Netherlands.

Mahmood K. 1987. Reservoir Sedimentation: Impact, Extent, Mitigation. World Bank Technical Report No. 71, Washington, DC.

Mee L.D. 1992. The Black Sea in crisis: a need for concentrated international action. Ambio 21: $278-285$.

Moroz S. 2003. Six Bad Examples of Water Management in Europe - WWF's Water and Wetland Index Phase 2. European Living Waters Programme. WWF Publications - EU Freshwater, www.panda.org.

Meade R.H., Yuzyk T.R. and Day T.J. 1990. Movement and storage of sediment in rivers of the United States and Canada. In: Wolman M.G. and Riggs H.C. (eds.), Surface Water Hydrology. Vol. 0-1. The Geological Society of America, Boulder, CO, pp. 255-280.

Morris G.L. and Fan J. 1997. Reservoir Sedimentation Handbook: Design and Management of Dams, Reservoirs, and Watersheds for Sustainable Use. McGraw-Hill, New York.

Panin N. 1996. Impact of global changes on geo-environmental and coastal zone state of the Black Sea. Danube Delta-Black Sea System under Global Change Impact. In: Malit A., Gomoiu M.-T. and Panin N. (eds.), Geo-Eco-Marina 1, pp. 1-6. 
Panin N., Jipa D.C., Gomoiu M.-T. and Secrieru D. 1999. Importance of sedimentary processes in environmental changes: lower River Danube-Danube Delta-Western Black Sea System. Kluwer Academic Publishers, Dordrecht.

Pennington V., Cambray R.S. and Fisher E.M. 1973. Observations on lake sediments using fallout ${ }^{137} \mathrm{Cs}$ as a tracer. Nature 242: $324-326$.

Perrsic M., Tutundzic V. and Milaorado M. 1991. Self purification and joint effects of the Iron Gate I Reservoir. Verh. Internat. Verein. Limnol. 24: 1415-1420.

Reschke S. 1999. Biogeochemische Variabilitäten in der Schwebstofffracht der Donau und deren Einfluß auf das Sedimentationsgeschehen im nordwestlichen Schwarzen Meer. Doktorgrades, Universität Hamburg.

RivDIS-v1.1 1994. The Global River Discharge Database. www.rivdis.sr.unh.edu/maps.

Robbins J.A. 1978. Geochemical and geophysical applications of radioactive lead. In: Nriagu J.O. (ed.), In: Biogeochemistry of lead in the Environment. Elsevier Scientific, Amsterdam, pp. 285-393.

Soler-López L.R. 2001. Sedimentation survey results of the principal water supply reservoirs of Puerto Rico. In: Sylva W.F. (ed.), Proceedings of the Sixth Caribbean Islands Water Resources Congress. Mayagüez, Puerto Rico, February 22 and 23.

Triplett L., Edlund M.B. and Engstrom D.R. 2003. A whole-basin reconstruction of sediment and phosphorus loading to Lake St. Croix. Final Project Report to the Metropolitan Council Environmental Services. St. Croix Watershed Research Station, Science Museum of Minnesota, 16910 152nd St. N. Marine of the St. Croix, MN 55047: (651) 433-5953 www.smm.org/SCWRS/ researchreports/LkStCroix2003report.pdf.

WCD 2000. Dams and Development - A New Framework for Decision-making. World Commission of Dams. Earthscan Publications Ltd, London and Sterling VA, USA.

WWF 2004. Dams in Europe: The Water Framework Directive and Beyond. www.panda.org/ dams.

Zessner M. and Kroiss H. 1998. Retention and Losses of Nutrients in the Hydrosphere. Institute for Water Quality and Waste Management, University of Technology, Vienna.

Zinke A. 1999. Dams and the Danube: Lessons from the Environmental Impact. World Commission of Dams, First WCD Forum, 25-26 March, 1999, Prague, Czech Republic, www.dams.org/commission/forum/forum_prague_zinke.htm. 